\title{
Fuentes para el estudio de los precios de los alimentos en los archivos municipales españoles en la Edad Moderna: los libros del juzgado de fieles ejecutores de Toledo ${ }^{1}$
}

\author{
Mariano García Ruipérez²
}

Recibido: 18 de octubre de 2016 / Aceptado: 21 de diciembre de 2016

Resumen. El estudio de los precios de los alimentos en la España Moderna, a través de los documentos conservados en los archivos municipales, se ha venido realizando con la ayuda de los libros de acuerdos y con los expedientes de contratación de obligados para los suministros básicos. Pocos ayuntamientos, tal vez solo Madrid y Toledo, han conservado libros registro en los que se refleje la actividad de los fieles ejecutores encargados de establecer el precio al que se debían vender los mantenimientos que llegaban al mercado, controlar su calidad o inspeccionar sus pesos y medidas. Estos libros que registraban las denuncias y penas en que incurrían los infractores o las posturas aprobadas cada día, junto con los aranceles generales o de tiendas, constituyen una fuente documental excepcional e inexplotada susceptible de ser utilizada en trabajos de historia económica, historia social, comercio interior, hábitos alimenticios, evolución de los precios, crisis agrarias, etc.

Palabras clave: España; Edad Moderna; ciudades; abastos; alimentos; precios; posturas; aranceles; ayuntamientos; fieles ejecutores; libros registro; fuentes documentales; archivos municipales; Toledo; Madrid.

\section{[en] Sources for the Study of Food Prices in the Spanish Municipal Archives at the Modern Age: The Legal Books of the Faithful Executors of Toledo}

\begin{abstract}
The study of food prices in Modern Spain is based on documents preserved in the municipal archives. It was carried out with the help of the books of agreements and the procurement records for the basic supplies. Few town halls, perhaps only Madrid and Toledo, have preserved record books in which is reflected the activity of the faithful executors. They were in charge of setting the price of the goods that came to the market, controlling their quality or inspecting their weights and measurements. These books registered the reports and penalties that incurred the offenders. Furthermore they contained the biddings adopted every day, along with the customs tariff. They constitute a source of exceptional and undeveloped documentary that can be used in projects of economic history, social history, internal trade, eating habits, evolution of prices, agrarian crises, etc.

Keywords: Spain; Modern Age; Towns; Supplies; Food; Prices; Biddings; Customs Tariff; Town Halls; Faithful Executors; Record Books; Documentary Sources; Municipal Archives; Toledo; Madrid.

1 Este trabajo forma parte del proyecto de investigación Familia, desigualdad social y cambio generacional en la España centro-meridional, 1700-1900, referencia HAR2013-48901-C6-6-R, que ha sido posible gracias a la financiación concedida por el Ministerio de Economía y Competitividad. El texto está dedicado a José Cepeda Gómez y a María Jesús Álvarez-Coca González. Su elaboración no habría sido posible sin la formación que recibí de ellos, mis maestros, en el campo de la Historia y de la Archivística.

2 Archivo Municipal de Toledo y Universidad de Castilla-La Mancha archivo@toledo.es
\end{abstract}


Sumario. 1. Introducción. 2. Los fieles ejecutores de Toledo y sus libros registro de penas y condenaciones. 3. Los libros registro de posturas de mantenimientos. 4. Los aranceles de vendedores y de tiendas. 5. Conclusiones.

Cómo citar: García Ruipérez, M. (2017) Fuentes para el estudio de los precios de los alimentos en los archivos municipales españoles en la Edad Moderna: los libros del juzgado de fieles ejecutores de Toledo, en Cuadernos de Historia Moderna 42.1, 261-290.

\section{Introducción}

La evolución de los precios de los alimentos en España durante la Edad Moderna ha sido realizada hasta ahora utilizando dos tipos de fuentes documentales de orígenes bien diferentes. Nos referimos a los libros de cuentas de conventos, hospitales y casas nobles, por un lado, y a las "mercuriales", por otro3. Los primeros serían generados por instituciones privadas mientras que las segundas fueron producidas por los ayuntamientos y deberían conservarse en sus archivos municipales.

Una mercurial es una lista, con formato librario o de cuaderno, de los precios medios (semanales o mensuales) de los granos y otros cereales que se vendían en el mercado, elaborada por las autoridades locales. Este tipo de fuente era muy común en Francia, pero no tanto en España en donde solo se conservan en algunas ciudades y casi siempre con datos de la segunda mitad del siglo XVIII y principios del siglo XIX. Los historiadores se han servido hasta ahora de las existentes en Tolosa, Palencia, Girona, Lérida, Tárrega, Cervera y, especialmente, de las conservadas en los archivos municipales de Segovia y Barcelona.

Han pasado cuarenta años desde la publicación del artículo que a Jean Paul Le Flem le sirvió para dar a conocer la "mercurial" segoviana. Por ella el hispanista francés entendía "una serie de precios de mercado, no de tiendas, es decir, de intermediarios entre los precios al por menor y los precios a granel", que fueron establecidos por el ayuntamiento segoviano, con una periodicidad variable (semanal o mensual) dependiendo de los géneros ${ }^{4}$, durante buena parte de la Edad Moderna (1540-1705). Esos datos eran apuntados cada semana en los libros de acuerdos municipales, tras la celebración del día de mercado (los jueves) al menos en el periodo que va de 1540 a 1650 . Con posterioridad a esa fecha las referencias de precios dejaron de ser semanales y, a partir de 1680, reflejaron ya medias mensuales. Los artículos recogidos eran casi en su totalidad alimentos (cereales, legumbres, arroz, queso, fruta, miel, azúcar, sal, vinagre, aceite y pescado), aunque también se incluía el jabón. ${ }^{5}$ Los precios eran recogidos en el acta de la sesión municipal por el escribano de la ciudad tras ser comunicados en ella a todos los presentes por dos fieles, miembros de la corporación segoviana. Uno era el de los nobles linajes y el otro el del común. Ahora bien, no estamos ante una serie documental nueva o única sino ante los tradicionales libros de acuerdos que en Segovia incluyen una información,

3 Anes, G.: Las crisis agrarias en la España Moderna, Madrid, Taurus, 1970. Sobre las fuentes para el estudio de los precios trata en su capítulo I, en concreto en las pp. 69-84.

4 Le Flem, J. P.: "Sociedad y precios en el Siglo de Oro: la Mercurial de Segovia (1540-1705)", Cuadernos de Investigación Histórica, núm. 1 (1977) p. 60.

5 Jean Paul Le Flem estimó en 156.000 los datos obtenidos en los libros de acuerdos municipales segovianos para el periodo 1540-1705. Al parecer también se recogían en otra serie formada por los "libros de medidores" hoy perdidos. 
la de los precios de los "mantenimientos", que en otras poblaciones no contienen, al menos de forma tan exhaustiva y periódica ${ }^{6}$.

La "mercurial" de Barcelona contiene datos de los años comprendidos entre 1711 y 1820 . Se trata de una lista de precios al por menor, principalmente de trigo, pero también de otros cereales panificables y de legumbres (judías, habas, guisantes y garbanzos) en el mercado de Barcelona en esos años?

Los avances notables que se han observado en la organización y descripción de archivos municipales en las últimas décadas no nos han aportado nuevos descubrimientos o, al menos, de existir, no se han hecho públicos. La evolución de los precios de los alimentos en España en la Edad Moderna, tras los estudios pioneros de Hamilton, sigue suscitando la atención de los especialistas de distintas áreas. Desde el campo de la historia económica podríamos citar ahora las aportaciones pioneras de J. Nadal y G. Anes o las más cercanas de Enrique Llopis Agelán y su equipo. De todas formas, la bibliografía es muy amplia. El comercio y el consumo de alimentos se recogen en infinidad de estudios. Datos sobre los precios de los productos alimentarios básicos para el periodo que nos ocupa tienen especial cabida en los trabajos de C. Cremades para Murcia, J. Moreno Lázaro para Palencia, D. S. Reher para Cuenca, J. Bernardos Sanz, J. Andrés Ucendo y C. Castro para Madrid, J. A. Mateos Royo y F. J. Montero para Zaragoza, J. M. Palop Ramos para Valencia, P. Vilar y G. Feliu i Montfort para Cataluña, etcétera ${ }^{8}$. La utilización en ellos de fuentes documentales municipales es muy desigual. Pero el establecimiento de los precios de los alimentos durante la Edad Moderna fue una competencia de las corporaciones locales y quedó reflejada en otros documentos, como más adelante veremos. Y de ello se ocuparon los tratadistas de la época.

Castillo de Bovadilla en su conocida obra dedicó un capítulo íntegro ${ }^{9}$ a la cuestión de los mantenimientos y al papel del corregidor en el control de los precios para evitar abusos y desórdenes, mostrándose partidario del sistema de obligados para el suministro de carne, pescado, aceite, vino y pan. En su obra también destacaría el papel de ciertos regidores, denominados "fieles del mes o presidentes o diputados", a quienes les competía establecer posturas ${ }^{10}$ en los alimentos que llegaban al mercado en las principales ciudades castellanas, por estar así establecido en sus ordenanzas municipales, en clara competencia con el propio corregidor.

Esta situación es descrita en muchos de los textos normativos locales de la época.

6 En otras ciudades, estos mismos libros incluyen información sobre precios pero de forma esporádica. Un ejemplo de la utilidad de esta fuente para el estudio de determinados precios puede verse en la obra de J. M. López Villalba, La actas de sesiones del concejo medieval de Guadalajara, Madrid, UNED, 1997. Pero hay muchos más.

7 Esta "mercurial" se conserva en el Archivo Histórico de la Ciudad de Barcelona en tres tomos. En el primer tomo los precios son mensuales pero en el segundo y tercero son diarios. Sobre esta fuente véase el texto de Gaspar Feliu, Precios y salarios en la Cataluña Moderna. Vol. 1. Alimentos, Madrid, Banco de España, 1991, especialmente pp. 11-13 y 24-25.

8 Sobre la actividad comercial, no sólo en relación con los alimentos, ofrece una buena visión de conjunto A. González Enciso en su artículo "El comercio en la España interior durante la Época Moderna”, Obradoiro de Historia Moderna, 17 (2008), pp. 15-42.

9 Castillo de Bovadilla, J.: Politica para corregidores..., Madrid, Imprenta de Joaquín Ibarra, 1759, tomo II, libro III, capítulo IV. De esta obra hay muchas ediciones desde la original aparecida en Madrid, en la imprenta de Luis Sanchez, en 1597. Este capítulo IV se intitula "De los abastos, provisión, tassa, y visita de ellos, y de las plazas, y lugares públicos". La referencia a los "fieles del mes" figura en su párrafo 69. Sobre las atribuciones en esta materia de los alcaldes de Corte trata en su párrafo 73.

10 Recordemos que el actual Diccionario de la Lengua Española de la RAE recoge como una de las acepciones del término "Postura" la de "Precio que la justicia ponía a las cosas comestibles". 
Un ejemplo es el que recogemos a continuación de la ciudad de León, datado en 1669:

Suelen y acostumbran las ciudades, villas y lugares de estos reinos tener personas diputadas para que entiendan en la administración de los mantenimientos que vienen de fuera parte a los pueblos, y para los otros mantenimientos que dentro del pueblo están y se venden que son de la cosecha, propios y rentas de los vecinos; las cuales personas para este efecto [son] diputadas. Ven los dichos mantenimientos, si son buenos o malos, si están para vender o no, si vienen sanos o dañados, si son útiles y provechosos o dañosos a las ciudades; y, conforme a la calidad de cada uno, les imponen precios y tasa, conforme y como se deban vender. Tienen las tales personas mucha preeminencia y dignidad por razón de su oficio; son muy privilegiados y honrados...11

En muchas poblaciones castellanas, especialmente medianas y grandes, sus corporaciones locales elegían a regidores por periodos concretos para que desempeñaran funciones relacionadas con el control de la calidad y del precio de determinados suministros, desarrollando también, en bastantes ocasiones, atribuciones judiciales, aplicando multas y penas a los infractores.

En las ciudades más grandes, los abastos más esenciales (como los señalados por Castillo de Bovadilla) recaían en obligados que se comprometían a ello durante un amplio periodo de tiempo (un año, por lo general) y a precios prefijados, consecuencia del correspondiente proceso de contratación que culminaba en una escritura pública $^{12}$. Había productos que podían encontrarse todo el año en tiendas abiertas (confiterías, botillerías, tabernas...) o puestos públicos, con precios establecidos por el ayuntamiento mediante aranceles, ofertados por mercaderes o tenderos de la localidad. La estabilidad en su precio estaba en teoría garantizada durante amplios periodos.

No ocurría lo mismo con los suministros que se vendían por foráneos, la mayoría de las veces, en determinadas plazas en los días de mercado. Eran productos ofertados por vendedores ocasionales (arrieros y carreteros de paso), por hortelanos, pescadores, cazadores... que vivían en la ciudad o en pueblos cercanos, y por mercaderes especializados en artículos concretos. A estos, los comisionados municipales debían darlos "postura" todos los días que se ofrecían en venta.

El sistema de comercialización se completaba con los regatones especializados en la reventa al por menor, y con los corredores que hacían de intermediarios en las compraventas, por mencionar a los principales actores. Al margen se situaban los grandes propietarios agrarios, las casas nobiliarias, los conventos y otros establecimientos similares que podían autoabastecerse de determinados productos (trigo, vino, aceite...) sin necesidad de acudir al mercado público.

Para la determinación de la postura de un mantenimiento ${ }^{13}$ concreto se combina-

11 Ordenanzas para el govierno desta muy noble, y muy leal ciudad de León..., León, Imprenta de Agustín Ruiz de Valdivielso, 1669, p. 22.

12 En el Diccionario de Autoridades (Tomo 5, Madrid, Imprenta de la Real Academia Española, 1737, p. 5) se indica que "Obligado", usado como sustantivo es "La persona a cuya cuenta corre el abastecer a un Pueblo o Ciudad de algún género como nieve, carbón, carne, etc., que porque hace escritura por tanto tiempo, obligándose a cumplir el abasto, se llamó assí".

13 Por "Mantenimiento" se entiende en esta misma obra (Tomo III, Madrid, Imprenta de la Real Academia 
ban diferentes criterios como el tipo de mercancía, su calidad y variedad, su abundancia o escasez, su origen, los gastos de su transporte y acarreo, la fiscalidad que le afectaba, etcétera. Los fieles conocían los precios dados en días anteriores a esos mismos productos y podían tener noticia de los que tenían en otras poblaciones cercanas. Obviamente debían dialogar con los vendedores para lograr la información precisa sobre los productos ofertados. Teniendo en cuenta todo ello determinaban su postura que era hecha pública a todos los interesados. Si el vendedor no estaba de acuerdo con el precio fijado podía llevarse la mercancía a otra localidad lo cual no siempre era factible teniendo en cuenta los tipos de productos llevados al mercado, por lo general muy perecederos, y el tiempo y gastos de su acarreo.

Las posturas era fijadas y hechas públicas mediante distintos medios (bandos o pregones ${ }^{14}$, tablas de madera con información escrita, cédulas o listas impresas en papel) para evitar que hubiera fraudes. En la fijación de los precios incurrían muchos criterios que podían favorecer situaciones de abuso. A veces las relaciones personales de vendedores y fieles comisionados condicionaban los precios en perjuicio de los consumidores. En todo caso las plazas debían estar bien surtidas y a precios razonables, lo que no siempre era fácil.

El estudio institucional de los fieles ejecutores en la Corona de Castilla lo pudimos abordar someramente hace años ${ }^{15}$ merced al contenido de varias ordenanzas municipales vigentes durante el Antiguo Régimen. Sabemos por ellas que fueron denominados fieles ejecutores en Salamanca, Sevilla y Toledo, ejecutores en Lorca, fieles de los bastimentos en Valladolid, fieles, sin más calificativos, en Burgos y León... Su número variaba según la ciudad y época (nueve en Sevilla, cuatro en Burgos y Salamanca, dos en León...) y podían desempeñar su cargo durante toda su vida (Sevilla), un año (Burgos), seis meses (Valladolid), cuatro meses (León), dos meses (Toledo), uno $\left(\mathrm{Madrid}^{16}\right)$, recayendo el cometido en regidores, casi siempre, acompañados de jurados allí donde estos existían. Su actividad era remunerada con salarios pequeños incrementados, en ocasiones, con los "derechos de posturaje" 17 que consistían en determinadas cantidades de los productos a los que ponían precio. A ello podían unir, los que además desempeñaban funciones judiciales, la parte que les correspondía de las multas que imponían a los defraudadores ${ }^{18}$.

Española, 1732, p. 488) "El alimento y sustento necesario para la vida".

14 En el Archivo Municipal de Toledo (AMT), en la caja 1153 de su Fondo Histórico, se conserva un cuaderno intitulado "Mandatos de los fieles ejecutores sobre los mantenimientos y otras cosas de gobierno" con documentos datados entre 1547 y 1659 , que contiene un buen número de pregones sobre precios de los alimentos en la ciudad de Toledo.

15 Lo hicimos conjuntamente con Francisco José Aranda Pérez en el texto titulado "Posturas y penas en el mercado. Los fieles ejecutores en Castilla en la Edad Moderna", publicado en La Administración Municipal en la Edad Moderna. II. V Reunión Científica de la Asociación Española de Historia Moderna, Tomo II, Cádiz, Universidad de Cádiz, 1999, pp. 349-358.

16 A finales del siglo XVIII los dos fieles ejecutores madrileños eran "semaneros". Es decir, ejercían sus funciones por semanas.

17 Estos derechos encarecían los bastimentos por lo que se llegaron a aprobar disposiciones prohibiendo su cobro. Así se recoge en las ordenanzas municipales toledanas al referirse al abasto de pescado que mencionamos en la nota siguiente. Y lo mismo ocurrió en otras ciudades. Así, en Córdoba, en 1733, su Corregidor dictó un auto mandando que los fieles ejecutores cumplieran las órdenes reales que prohibían llevar derechos por las posturas de los mantenimientos.

18 En las ordenanzas de la ciudad de Toledo, compiladas a finales del siglo XVI, se da cuenta del cobro por los fieles ejecutores de una tercera parte del valor de las penas impuestas a diversos infractores. En concreto se refleja en el título 42 (de los carniceros), título 47 (de los corredores), título 52 (de la corambre), en el 54 (del carbón)... Véanse las Ordenanzas para el buen régimen y gobierno de la ... ciudad de Toledo, Toledo, Imprenta de José de Cea, 1858, pp. 82, 92, 104, 106..., prologadas por Antonio Martín-Gamero. Este texto fue estudiado 
Poner precio a los mantenimientos, vigilar la calidad de los productos ofertados, visitar las tiendas y controlar la exactitud de los pesos y medidas utilizados en los mercados eran sus cometidos básicos. A ellos se unía sancionar a los infractores, aunque esta función no siempre recaía en estos fieles. Estas tareas las debían realizar, además, todos los días que hubiera mercado, por las mañanas, desde horas muy tempranas. La presencia de escribanos municipales podía suponer que esas actividades quedaran reflejadas por escrito en diferentes registros. Pero esto último fue muy inhabitual salvo, tal vez, en las ciudades de Toledo y Madrid.

La actividad de la Sala de Alcaldes de Casa y Corte en el establecimiento de los precios de los alimentos en Madrid ha sido estudiada con la ayuda de sus libros de gobierno, que se conservan en el Archivo Histórico Nacional ${ }^{19}$. Se ha destacado su papel en la fijación de precios ${ }^{20}$, en la concesión de licencias para la venta, en el control de los fraudes y en la vigilancia de los establecimientos. Pero a nuestro entender los especialistas no han utilizado como debieran el importante fondo documental generado por el Repeso de Madrid. En el Archivo de Villa se conservan en la actualidad 48 legajos generados por esa institución con documentos datados entre 1654 y 1848 (aunque existe un cuaderno de fechas anteriores). Su contenido fue catalogado en $1867^{21}$ y los datos que nos ofrecen sobre los precios en la ciudad de Madrid son excepcionales tanto por la riqueza cuantitativa como por la continuidad de sus series documentales. El mercado de la capital era el principal del país y a él llegaban infinidad de productos con orígenes muy variados. En su control, el Repeso Mayor ${ }^{22}$ generó libros de posturas de mantenimientos desde 1654 hasta 1811, libros de penas y condenaciones (desde 1703), libros de providencias y multas, bandos y aranceles impresos, licencias de ventas... Y algo similar ocurrió en la ciudad de Toledo y de ello vamos a dar cuenta a continuación.

\section{Los fieles ejecutores de Toledo y sus libros registro de penas y condenaciones}

Los antecedentes de este oficio municipal toledano se remontan al reinado de Alfonso $\mathrm{X}$ cuando se nombraron tres caballeros y tres ciudadanos para la vigilancia del mercado. Pero su regulación más completa se producirá en 1481 mediante una Real

hace años por Enrique Lorente Toledo en su Gobierno y administración de la ciudad de Toledo y su término en la segunda mitad del siglo XVI, Toledo, Ayuntamiento, 1982.

19 Alfaro Roca, A. L.: "Fuentes para el estudio del consumo y del comercio alimentario en Madrid en el Antiguo Régimen", en Primeras Jornadas sobre fuentes documentales para la Historia de Madrid, Madrid, Consejería de Cultura, 1990, pp. 279-288; y Villalba Pérez, E.: “Corte y Orden Público. El control de precios y abastos por la Sala de Alcaldes de Casa y Corte (Fin. XVI-Prin. XVII), en Ortiz De OrRuño Legarda, J. M y Castillo Alonso, S. (coord.): Estado, protesta y movimientos sociales: actas del III Congreso de Historia Social de España: Vitoria-Gasteiz, julio de 1997, [Bilbao]: Universidad del País Vasco, 1998, pp. 29-34.

20 Estos libros son anuales, aunque algún tomo agrupa varios años. De todas formas la serie no está completa. En ellos se incluyen "aranceles de posturas".

21 El "Registro del Archivo del Repeso de Villa de Madrid" se identifica como "L. M. 78" en el Archivo de Villa (AVM). Los 48 legajos de este fondo concreto contienen expedientes y libros. Agradezco a Carmen Cayetano Martín, directora del Archivo de Villa de Madrid, su ayuda en la localización de este fondo y en la consulta de sus documentos.

22 Entre los documentos que nos ayudan a conocer la historia del Repeso Mayor destacamos el contenido del legajo 19 que contiene las "Ordenanzas de S.M. para la administración del Peso Real” de 28 de abril de 1756 y una "Instrucción y reglas que deben observarse en la Administración del Peso Real..." de 31 de diciembre de 1789. En el legajo 20 se incluye el "Libro prontuario de noticias y providencias generales del Repeso Mayor" (1784-1805)". 
Provisión de la Reina Isabel dada en Valladolid el 8 de marzo de ese año ${ }^{23}$.

Por ella sabemos que hasta ese año estos oficios habían sido perpetuos, es decir eran desempeñados por personas que los tenían vinculados sin que el Ayuntamiento interviniera en su nombramiento. A partir de entonces, y una vez que quedaran vacantes por renuncia, traspaso o fallecimiento de los que entonces los desempeñaban, serían designados por la corporación municipal que elegiría para ello a dos personas hábiles por un año o menos tiempo. En la disposición mencionada no se especifica si debían ser o no miembros del Ayuntamiento.

Ya entrado el siglo XVI estos empleos públicos serían ejercidos por regidores, iniciando entonces el cabildo de jurados un largo pleito para que dos de sus miembros compartieran con ellos estos cometidos, como ocurría con otras comisiones municipales toledanas. Y no lo consiguieron hasta la aprobación de una Real Cédula por Felipe II, de 18 de mayo de 1559, en la que hizo merced a Toledo del nombramiento de cuatro fieles ejecutores, dos del cabildo de regidores y otros dos del cabildo de jurados ${ }^{24}$, existiendo uno más que las fuentes denominan "fiel executor de los ciudadanos". Este último ya no era nombrado a finales de ese reinado. Su manera de actuar queda reflejada en las ordenanzas toledanas de la época:

Que los señores fieles executores que son o fueren de aqui adelante, los martes de cada semana se informen muy particularmente del valor y precios de como passan y valen a aquella sazón todas las cosas de mantenimientos que a esta ciudad vinieren, para que sean los precios y posturas de manera que sean justas y moderadas; y tengan especial cuydado y atención, a que los que vienen a vender a esta ciudad, y los vezinos della que los compran para los tornar a vender, sean bien tratados y beneficiados en las dichas posturas, de manera que ganen, y no tomen ocasión de las dichas posturas para no las poder guardar, havida en todo consideración al tiempo en que las hazen, para que otro día miércoles siguiente de cada semana, informados de lo susodicho, y de los precios a que hasta allí han valido, suban o baxen los precios, conforme a lo susodicho: hallándose presentes a lo susodicho, y a las dichas posturas, todos los señores fieles executores, o la mayor parte dellos, assignando hora en que se hagan, para que todos estén presentes, o la mayor parte. $\mathrm{Y}$ ninguna postura se pueda hazer de otra manera, y si se hiziere no se guarde ${ }^{25}$.

En ellas también se recuerda a los tratantes, regatones y mercaderes la obligación de cumplir las posturas establecidas ${ }^{26}$ bajo determinadas penas que podían llegar hasta la prohibición de vender o comprar en la ciudad de Toledo o, incluso, al cierre de sus tiendas por un periodo de dos meses.

A principios del siglo XVII, por Real Cédula de 21 de junio de 1601, Felipe III otorgó a los fieles ejecutores toledanos las mismas atribuciones judiciales que tenían los fieles sevillanos ${ }^{27}$. Por este texto sabemos que en esa época la ciudad nombraba

23 El documento original se conserva en la actualidad en el AMT, en el cajón 1, legajo 7, número 1 de la agrupación conocida como Archivo Secreto. Fue transcrito por R. Izquierdo Benito en su libro Privilegios Reales otorgados a Toledo durante la Edad Media (1101-1494), Toledo, Diputación Provincial, IPIET, 1990, pp. 289-291.

24 AMT, Fondo del Cabildo de Jurados, documento núm. 153.

25 Ordenanzas para el buen régimen y gobierno de la ... ciudad de Toledo... Título setenta, de los fieles executores, p. 115.

26 Así se recogen en las que tratan, por ejemplo, de los acarreadores (título 23), de los alcaceles (título 29), de la caza (título 41), etc.

27 En el Archivo Municipal de Sevilla no se conservan registros de las actividades realizadas por sus fieles 
cada mes, en su primer ayuntamiento, un regidor y un jurado como fieles ejecutores que ejercían sus funciones durante dos meses por lo que siempre había cuatro fieles, dos de cada cabildo. O sea que, aunque eran cuatro, sus nombramientos y ceses no coincidían, relevándose cada mes de dos en dos, lo que ayudaba en la toma de decisiones. Por entonces su cometido consistía en:

Hazer posturas en los mantenimientos por menor, en las plazas de essa ciudad, y mirar que sean de la calidad y bondad necessaria. Y visitan los pesos y medidas, y las tavernas y casas donde se vende de comer, y la texa y ladrillo, y cántaros de los aguadores, para ver si están conforme a la marca, y hazen las causas contra las personas que tienen pesos y medidas falsas, o exceden del precio de las posturas. Y que para sentenciar las dichas causas, essa ciudad nombra un Regidor y un Jurado, que se juntan con el Alcalde mayor, y las sentencian conforme a las ordenanzas, ante el escribano de nuestro Ayuntamiento, el qual tiene un libro en que assienta las penas $^{28}$, y otro semejante tienen los fieles executores ${ }^{29}$.

Es decir, las causas abiertas por cada uno de los fieles ejecutores en los días precedentes eran sentenciadas, indicando la cuantía definitiva a abonar, en reuniones conjuntas celebradas en las casas consistoriales, generalmente los sábados por la tarde, bajo la presidencia del alcalde mayor o del corregidor ${ }^{30}$, y ante el escribano municipal. Las "condenaciones" aprobadas eran asentadas por este oficial en un libro que recogía las actas de esas audiencias públicas del Juzgado de Fieles Ejecutores comenzando por la fecha, el lugar y los nombres de los miembros del tribunal. A continuación, en breves frases se daba cuenta, una por una, de las denuncias efectuadas y de las penas acordadas, casi siempre pecuniarias. Terminaba el acta con frases del tipo "visto lo cual se acabó esta audiencia y se hicieron las dichas condenaciones en la forma que va declarado y lo firmaron...", por lo que a continuación se recogían las firmas de los miembros del Juzgado, y la del escribano precedida de la expresión "Pasó ante mí". Esas sesiones, en principio semanales, pudieron irse espaciando con el paso del tiempo de tal forma que encontramos reuniones del Juzgado realizadas una vez al mes e incluso tras periodos más amplios ya entrado el siglo XVII. Pero sabemos que su actividad se mantuvo hasta principios del siglo XIX ${ }^{31}$.

A ellas podían asistir los denunciados aunque no conocemos si podían intervenir o no. Además solo en "cosas de consideración" se abría "proceso", como ocurría si el fiel ordenaba el encarcelamiento del infractor ${ }^{32}$. Esto nos lleva a pensar que

ejecutores.

28 Hacia 1930, cuando Antonio Sierra Corella escribió su artículo titulado "El Archivo Municipal de Toledo. Estudio y relación de sus fondos", aparecido en el Boletín de la Real Academia de la Historia, 98: II (1931), pp. 665-769, indicó, en la p. 704, la existencia de "ocho volúmenes" de "Libro de penas impuestas por los fieles ejecutores desde el año 1573 al 1604”. Pero hay más y de otros años.

29 Ordenanzas para el buen régimen y gobierno de... Toledo, p. 116.

30 Con la reforma de 1601 parece que estas audiencias eran presididas por el "fiel ejecutor de la vara", letrado nombrado por el corregidor, como ocurría en Sevilla, aunque este cambio duró pocos años.

31 En el AMT se conserva un libro, encuadernado en pergamino, pero con todas sus hojas en blanco, en cuya cubierta se puede leer "Libro del Juzgado de Señores Fieles Executores de esta Ymperial Ciudad de Toledo, donde se sienten las penas y condenaciones que impone...", formado por 200 hojas en papel sellado de 1803.

32 Apenas se conservan causas en el AMT, tramitadas por este Juzgado de Fieles Ejecutores, formando cuadernos o expedientes individualizados. Una de ellas se tramitó en 1660 contra Isidro Pedregal, pastelero, por utilizar en sus pasteles carne de mala calidad, y en la que incluso se llegó a utilizar el tormento de mancuerda con uno de sus criados para averiguar la verdad. El reo fue penado con doscientos azotes, seis años de destierro y una multa 
raramente se trasladaron a otros documentos textuales las distintas actuaciones judiciales ordinarias, bastando solo con los datos recogidos en los registros, ya que el procedimiento seguido era sumario, por lo que se prescindía de muchos trámites y formalidades $^{33}$. Se pretendía con ello evitar que los gastos procesales fueran muy superiores a la cuantía de las posibles sanciones pecuniarias.

De las sentencias dadas por este Juzgado únicamente se podía apelar ante el ayuntamiento de Toledo ${ }^{34}$, salvo casos excepcionales.

De todo lo comentado hasta aquí dio cuenta el escribano municipal Juan Sánchez de Soria, en 1634, en su libro manuscrito Toledo: Su prudente gobierno y las corteses ceremonias con que le ejerce ${ }^{35}$. En esta obra detalla la actividad de los fieles ejecutores toledanos ayudados en sus quehaceres por cuatro alguaciles porteros, y la celebración de sus audiencias, en una de las salas del Ayuntamiento, los sábados por la tarde. Tiempo después, las realizaron en un espacio construido con ese fin en la planta baja de un inmueble situado en la plaza de Zocodover que utilizaban especialmente los martes, día de mercado ${ }^{36}$.

La existencia de estos libros registro de penas o condenaciones acordadas por el Juzgado de Fieles Ejecutores en sus audiencias públicas puede remontarse al menos al año 1529 en el que por Real Provisión de 26 de mayo de ese año, Carlos V aprobó la ordenanza municipal que establecía el reparto de las penas impuestas por ese Juzgado. Hasta entonces su cuantía había sido distribuida entre el acusador (una tercera parte) y la ciudad (las otras dos), pero a partir de ese año se distingue entre las penas "que son de ley" y las "que son de ordenanza". Las primeras se distribuirían por tercias partes entre el juez, el denunciador y los fieles ejecutores; y las segundas, en la misma proporción, entre el almotacén, el denunciador y la ciudad (para los reparos de sus muros). Con ello se pretendía que "cada uno de los fieles ejecutores resida y ejecute mejor su oficio" 37 al percibir ya una remuneración por su trabajo.

Las penas aprobadas en 1529 oscilaban entre los 200 maravedís (la primera vez) y los 400 (la segunda). Al que reincidiera por tercera vez se le castigaba con cien azotes. Con el paso del tiempo estas sanciones sufrieron variaciones.

Estos libros servían obviamente para controlar las cantidades recaudadas y establecer su distribución entre las partes indicadas. Cada uno de ellos suele abarcar

de 30.000 maravedís. Esta extensa causa se conserva en la caja 1153 del AMT. En ella también existen ejemplos documentales de los conflictos de competencias entre el Juzgado de Fieles y el corregidor de Toledo. Uno de ellos motivó una Real Cédula de Felipe III, de 28 de junio de 1619, confirmando las atribuciones judiciales del Juzgado de Fieles, reconocidas desde 1601.

33 En algunos documentos se menciona que lo recaudado por el Juzgado procedía de "multas verbales" lo que nos reafirma en lo expuesto. Véase AMT, libro mss, sección B, núm. 600, fol. 155. El día 14 de abril de 1791 los fieles ejecutores entregaron al depositario de los efectos de penas de cámara y gastos de justicia de los juzgados de Toledo la cantidad de 7 reales de vellón "por multas verbales" impuestas ese mismo día en el Juzgado de la plaza Mayor.

34 Un ejemplo de estas apelaciones, realizado el 25 de agosto de 1621, lo encontramos en la hoja 18v del libro núm. 584A. Indicamos ahora que todos los libros manuscritos referenciados en este artículo del AMT se conservan en su sección B. La sección A está formada por los libros de acuerdos municipales.

35 SÁnCHEZ de Soria, J.: Toledo: su prudente gobierno y las corteses ceremonias con que le ejerce / Introducción, transcripción y notas de Mariano García Ruipérez, Toledo, Ayuntamiento, 2004, pp. 59-61.

36 Tras el grave incendio sufrido por los inmuebles de la plaza de Zocodover, esa Audiencia fue reconstruida entre los años 1673-1674. Podemos conocer su disposición arquitectónica porque se han conservado sus planos. Véase AMT, Colección de planos y dibujos originales, números 35, 36 y 37.

37 En 1614, según se recoge en la primera hoja del "Libro del almotacenazgo" se realizaba una distribución diferente. De todas las condenaciones efectuadas por el Juzgado de Fieles Ejecutores la mitad de lo recaudado se repartía en cinco partes iguales que recibían los cuatro fieles y el alcalde mayor. La otra mitad se dividía en dos partes, una para la ciudad y otra para el almotacén. Véase AMT, libro núm. 464. 
las sesiones celebradas por el Juzgado durante varios años. En la actualidad se conservan siete libros con estas características que proporcionan datos de 26 años en el periodo comprendido entre 1529 y $1604^{38}$.

El control de las denuncias de cada jornada lo realizaban los fieles en otros libros, como nos indica la Real Cédula comentada de 1601. Muy posiblemente cada fiel, acompañado por su alguacil portero, anotaría las multas impuestas cada día en alguna libreta particular ${ }^{39}$. Después, poco antes de celebrar la audiencia pública semanal, cada uno de ellos trasladaba esos datos a un libro común "que tiene el almotacén mayor ${ }^{40 "}$, tal y como nos lo indicó Juan Sánchez de Soria.

Estos registros eran un poco diferentes a los anteriores y, además, se nota que sus asientos, en un número cercano, de media, al millar por año, eran redactados por diferentes manos y no por el escribano municipal. El orden en ellos es un poco confuso. De cada fiel se anotan las "penas que toman" a distintas personas, que serían examinadas y sentenciadas en la siguiente audiencia, por orden cronológico pero no siempre preciso. Cuando se registran todas las "tomadas" por uno de los fieles desde la última audiencia del Juzgado, se continuaba con el siguiente, y así sucesivamente. Es más, determinadas penas como las que afectaban a fraudes en la venta o calidad del pan se relacionaban de forma diferenciada en los últimos cuadernillos del libro registro. Por lo expuesto entendemos que el almotacén (o alguno de sus empleados) acompañaba al fiel o fieles ${ }^{41}$ en sus inspecciones diarias y recibía a cuenta el dinero "tomado" de los infractores. Pero esa cantidad no era definitiva hasta que el Juzgado no pronunciara su sentencia sobre esas causas en sus audiencias periódicas.

De todas formas, en las hojas de estos libros se suele estructurar su información, aunque no de una manera uniforme, en tres bloques a manera de columnas incluyendo una media de cuatro o cinco asientos por página. En su parte izquierda figura el nombre del fiel o fieles que iniciaba la causa, casi siempre abreviado con el término "el dicho" o "los dichos" para no repetir ese dato continuamente.

La descripción, en la parte central de la página del libro, comenzaba con la data, recogida también de forma incompleta (mención del día y del mes) en el primer

38 Los libros registro de penas y condenaciones impuestas por el Juzgado de Fieles Ejecutores de Toledo en audiencia pública conservados en el AMT son los siguientes: Libro núm. 580 (asientos entre el 13 de julio de 1529 y el 7 de marzo de 1539), libro 793 (1 de marzo de 1550 a 15 de marzo de 1553), 794 (16 de mayo de 1573 a 14 de julio de 1575), 581 (22 de octubre de 1583 a 15 de octubre de 1588), 797 (12 de noviembre de 1588 al 20 de septiembre de 1591), 460 (12 de julio de 1601 a 13 de agosto de 1601) y 798 (13 de agosto de 1601 a 4 de agosto de 1604).

39 Lo mismo ocurría en Madrid. Cada fiel de vara generaba su propio libro de denuncias diferenciado. Así, del año 1735 se conservan el de Antonio López Alba y el de Esteban Salats en el legajo 32, núm. 11 y 9, del fondo del Repeso Mayor del AVM. En los fieles de vara recaía la administración de justicia y ejercían su cargo durante un año. Los fieles ejecutores madrileños no juzgaban.

40 La RAE define "Almotacén" como el "empleado público que contrastaba pesas y medidas" pero en Toledo tenía otros cometidos. Entre sus bienes de propios, el Ayuntamiento arrendaba periódicamente la "renta del almotacenazgo". Su arrendador percibía determinadas cantidades, establecidas por arancel, que gravaban la entrada en la ciudad de todo tipo de pescados por los forasteros. También percibía derechos por la entrada de tocino, fruta, ajos, nabos, capullos de seda, escobas, tinajas, semillas, lino... y de las medidas que se hubieran de registrar. Además le pertenecía "la tercia parte de las penas que denunciaren con los señores fieles executores, conforme a la costumbre y ordenanzas desta ciudad". Todo ello se recoge en el "Libro de aranceles de Toledo", escrito en 1562 y conservado en AMT, cajón 6, legajo 1, núm. 11. Sobre su contenido trató E. Sáez Sánchez en su artículo "Aranceles de Toledo", publicado en el Anuario de Historia del Derecho Español, XIV (1942-1943), pp. 546-560. De la renta del almotacenazgo se ocupa en las pp. 549-550.

41 Las "penas eran tomadas" generalmente por un fiel o por dos, nunca por los cuatro, lo que nos hace suponer que se dividían para realizar sus quehaceres y rutas por la ciudad. 
asiento de esa fecha, mientras que en los siguientes simplemente se da cuenta de "este día" o "este dicho día". A continuación se escribe el nombre del infractor, generalmente acompañado de su primer apellido y de su oficio y, a veces, del barrio o calle en el que vive, o de su mote; es decir, de la información que se entendía suficiente en la época para su correcta identificación. Continúa el asiento reflejando el motivo de la posible sanción: "porque estaba pesando tocino añejo hediondo", "porque se le hallaron las medidas de vino melladas", "porque vendía los peces sin postura", "porque a las siete de la mañana estaba en el mesón de la fruta no pudiendo estar hasta las doce", "porque estando puestas las velas chicas a dos maravedíes las vendió a tres", "porque estando pregonado que ningún tratante descargue cabrito en su casa sino en la carnicería el dicho descargó en su casa"... Las causas podían ser, pues, muy variadas. En ocasiones se menciona también el nombre de la persona que había sufrido y tal vez denunciado el abuso. La rúbrica del fiel ejecutor o ejecutores ponía fin a ese párrafo (al menos en algunos de estos registros).

En la parte derecha de la página del libro se incluía la cuantía de la pena tomada, en maravedís, con cifras romanas ( $\mathrm{L}, \mathrm{C}, \mathrm{CC} \ldots$... Esa cifra podía ser modificada (los tachones son perceptibles en algunos asientos) o "suspendida", si así lo decidía el Juzgado. Y junto con la cantidad a pagar se recogía la rúbrica de la persona que recibía el dinero recaudado, posiblemente el almotacén, alguno de sus oficiales o algún otro receptor o depositario municipal.

En la actualidad se conservan doce libros con las características señaladas datados entre 1585 y 1614. Cada uno de ellos solo contiene asientos durante un año (de principios de marzo a finales de febrero del siguiente) por lo que es factible pensar que tuvieran una clara finalidad hacendística ${ }^{42}$.

Además en este Archivo hay otros tres libros, con datos similares a los comentados, pero de los años 1621 a 1636 y con un contenido un poco diferente ${ }^{43}$. Parecen reunir en ellos la información que hasta entonces se repartía en los dos tipos de registro ya descritos. No son anuales, pues tienen asientos de varios años pero no tienen la estructura de actas, como los de las audiencias públicas del Juzgado de Fieles. Da la impresión de que son los que llevaba el almotacén, si tenemos en cuenta lo que escribió por entonces Juan Sánchez de Soria, aunque ahora se han completado incluyendo, cada ciertas páginas, el acuerdo original del Juzgado, de la fecha en la que hacían sus reuniones, conformándose con las penas tomadas, que aparecían anotadas en sus hojas anteriores, y ordenando su cobro, en un párrafo formado por unas pocas líneas pero refrendado con las firmas autógrafas de los miembros del Juzgado ${ }^{44}$.

42 Estos libros los hemos descrito como "Libro donde se asientan diariamente, por el almotacén de Toledo, las penas tomadas a diferentes vendedores y tenderos por los fieles ejecutores de la ciudad, entre...". Conservamos los siguientes: núm. 795 (1584-1585); 796 (1585-1586); 578 (1590-1591); 459 (1600-1601); 460 (1601); 582 (1604-1605); 461 (1605-1606); 462 (1606-1607); 463 (1609-1610); 583 (1611-1612) 577 (1613-1614; y 464 (1614-1616). Todos estos libros contienen anotaciones entre principios de marzo y finales de febrero de las fechas indicadas entre paréntesis, salvo el 460 que incluye solo de 2 de marzo a 6 de julio de 1601. El único libro que tiene datos de dos anualidades completas es el 464. Pocos de ellos están intitulados. El que tiene un título más completo es el libro 577. En su cubierta en pergamino aparece: "Libro del año de mil y seiscientos y treze donde se asientan las penas que cojen los señores fieles executores rexidores y jurados desta ciudad de Toledo y de los Juzgados que en raçon dellas azen el señor alcalde mayor y los dichos señores siendo almotacén mayor Diego de Çavallos". Otros simplemente recogen en ella "Almotacenazgo" o "Libro del Almotacenazgo".

43 Nos referimos al libro núm. 584A (asientos de 9 de marzo de 1621 a 9 de noviembre de 1626), al núm. 465 (de 16 de mayo de 1627 a 9 de abril de 1633) y al núm. 584B (de 14 de junio a 4 de octubre de 1636).

44 Como ejemplo recogemos el que figura en el Libro núm. 465: "En la ciudad de Toledo a veinte y seis de hebrero de mill y seiscientos y treinta y tres años los señores alcalde mayor y fieles executores sentenziaron las penas y 
Pero el control de las penas requirió, al menos durante unos años concretos (15361544), la existencia de otro registro no cronológico sino alfabético ${ }^{45}$. Para conocer las personas que incumplían reiteradamente las ordenanzas sobre mantenimientos fue preciso abrir ese libro con asientos ordenados por los nombres de los denunciados, precedidos de un índice en forma de abecedario escalonado (de la $\mathrm{A}$ la $\mathrm{Z}$ ) que facilitaba las búsquedas.

Los diferentes tipos de registros mencionados, en los que se da cuenta de las penas y condenaciones impuestas por el Juzgado de Fieles Ejecutores, abarcan un periodo que va de 1529 a $1636^{46}$, aunque no son los únicos que nos ofrecen datos sobre la actividad de estos magistrados ya que a estos libros hay que unir otros cuadernos de penas impuestas, conservados sin la protección de cubiertas duras, es decir sin formato librario, y que se datan también en los siglos XVI y XVII ${ }^{47}$.

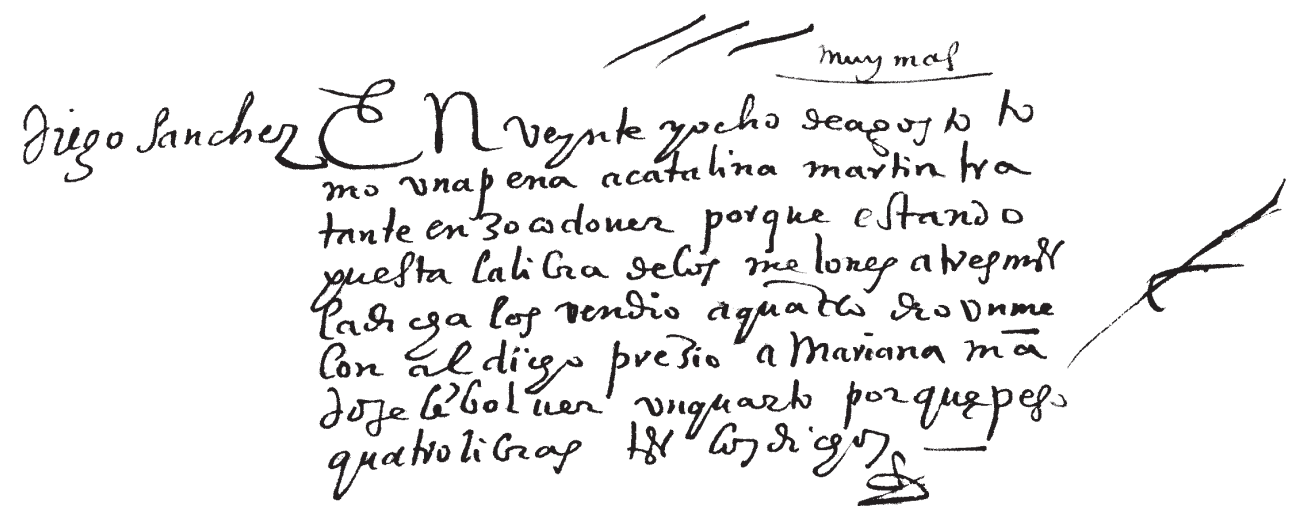

Imagen 1. Asiento de imposición de pena por el Juzgado de Fieles.1590-08-28.

AMT, libro núm. $578^{48}$.

A través de ellos podemos conocer las principales faltas cometidas por comerciantes y vendedores (venta de productos sin precio de postura, o por encima del precio fijado, en lugares y días no regulados, utilizando pesos no contrastados, etc.). Estos libros son una fuente documental de excepcional valor informativo para conocer el día a día en el sistema de abastecimiento al por menor de la ciudad de Toledo. Posiblemente cerca de la mitad de sus asientos contienen datos sobre los precios de los alimentos que se comercializaban en el mercado de esta ciudad castellana con

condenaciones contenidas antes deesto en las cantidades questan puestas a la margen y mandaron se cobren y lo firmaron. [Firmas y rúbricas].

45 Solo hemos localizado un "Libro registro por orden alfabético de las personas sentenciadas por el Juzgado de Fieles Ejecutores" identificado en la actualidad con el núm. 799 entre los libros manuscritos de la sección B de este Archivo.

46 Si tenemos en cuenta las fechas de los diferentes tipos de registros comentados, en el AMT se conserva información sobre las penas y condenaciones impuestas por ese Juzgado entre 1529-1544, 1550-1553, 1573$1575,1588-1591,1601-1607,1609-1616,1621-1633$ у 1636.

47 Véase AMT, Fondo Histórico, cajas 1151, 1152 y 1153.

48 En concreto se indica lo siguiente: "En veynte y ocho de agosto tomó una pena a catalina martín tratante en zocodover porque estando puesta la libra de los melones a tres mrs. la dicha los vendió a quatro, dio un melón al dicho precio a mariana, mandosele volver un quarto porque pesó quatro libras, testigos los dichos [rúbrica]" 
escasos recursos agrarios y ganaderos, pues no en vano fue definida por Luis Hurtado de Toledo, en 1576, como de "industria y de acarreo"49. Es decir, para su abasto dependía en gran medida de una compleja red comercial en la que intervenían muchos actores y condicionantes, dada su ubicación en la Castilla interior. Ahora bien, estos libros no son los únicos conservados en el Archivo Municipal que nos aportan información sobre los precios de los alimentos en Toledo, ni siquiera son los más importantes.

\section{Los libros registro de posturas de mantenimientos}

El estudio de la evolución de los precios de los productos de primera necesidad en Toledo se ha realizado, como en otras muchas ciudades, utilizando fuentes documentales de instituciones privadas. Para el siglo XV hemos de subrayar las aportaciones de R. Izquierdo Benito que se sirvió fundamentalmente del contenido de los libros del archivo de obra y fábrica de la Catedral de Toledo ${ }^{50}$. Para la Edad Moderna son de sobra conocidos los trabajos de Earl J. Hamilton que en 1934 publicó su libro sobre El tesoro americano y la revolución de los precios (1501-1650), que no sería traducido al español hasta el año $1975^{51}$. Esta obra la continuaría con su Guerra y precios en España, 1650-1800, aparecida en 1947, con una primera edición en nuestro país en $1988^{52}$. El historiador norteamericano se sirvió en Toledo de los libros de cuentas del Hospital de San Juan Bautista o Tavera ${ }^{53}$ y también utilizó, pero en menor medida, los del monasterio de San Pedro Mártir. En su obra de 1947 incluyó un extenso apéndice de "Precios de los productos en Castilla la Nueva", entre 1650 y 1800 , aportando medias de precios anuales de casi un centenar de ellos suministrados en esos hospitales toledanos, pero no consultó documentos municipales ${ }^{55}$. Su trabajo en relación con Toledo y pueblos cercanos ha sido examinado últimamente por David González Agudo en su tesis doctoral ${ }^{56}$.

49 Maravall, J. A.: "Dos términos de la vida económica: La evolución de los vocablos Industria y Fábrica", Cuadernos Hispanoamericanos, 280-282 (1973) p. 647. El gran historiador expresó que la primera e inesperada mención de la palabra "industria" con su sentido actual se recoge en esa relación elaborada por Luis Hurtado de Toledo en 1576 .

50 IzQuierdo Benito, R.: Precios y salarios en Toledo en el siglo XV (1400-1475), Madrid, Fundación Juan March, 1982 [Otra edición por la Caja de Ahorro Provincial de Toledo en 1983]; Ídem, "La actividad comercial en Toledo a fines de la Edad Media (1450-1475)", en Tolède et l'expansión urbaine en Espagne (1450-1650), Madrid, Casa de Velázquez, 1991, p. 137-157; Ídem, Abastecimiento y alimentación en Toledo en el siglo XV, Cuenca, Ediciones de la Universidad de Castilla-La Mancha, 2002.

51 Hamilton, E. J.: El tesoro americano y la revolución de los precios en España, 1501-1650, Barcelona, Ariel, 1975.

52 Sobre la importancia de las obras de Hamilton existe abundante bibliografía. Remitimos, por ejemplo, al texto de Ernesto López Losa, "El legado de Earl J. Hamilton. Nuevos datos para el estudio de los precios en España, 1650-1800”, Investigaciones de Historia Económica, Vol. 9:2 (Junio 2013), pp. 75-87.

53 En el prefacio de su obra El tesoro americano... agradece la colaboración recibida de un buen número de archiveros españoles. Y en concreto en Toledo lo hace de Agustín Rodríguez "Director del Hospital Tavera".

54 Hamilton, E. J.: Guerra y precios en España, 1650-1800, Madrid, Alianza Editorial, 1988, pp. $273-308$.

55 El propio Hamilton escribió que "Las cuentas municipales que suministraron las inestimables estadísticas de precios y salarios para los periodos comprendidos entre 1351-1500 y 1501-1650 no han sido utilizadas en este estudio debido a que otras fuentes alternativas eran mucho mejores y los registros municipales mucho peores que en los periodos precedentes". Véase Ídem, p. 126. Incluso en su libro El tesoro americano y la revolución ... (1975), p. 154, manifestó que "los materiales encontrados en ayuntamientos y catedrales nos brindaron algunos datos, pero en conjunto estas fuentes son decepcionantes".

56 González Agudo, D.: Población, precios y renta de la tierra en Toledo, siglos XVI-XVII, Tesis doctoral 
番

\section{MODER ACION}

\section{DE PRECIOS DE TODOS \\ GENEROS COMERCIABLES,}

hecha en virtud de Real Prouifion de fu Mageftad, y feñores de fu Real Confejo, P O R

La Imperial Ciudad de Toledo. Ańo de 1680 .

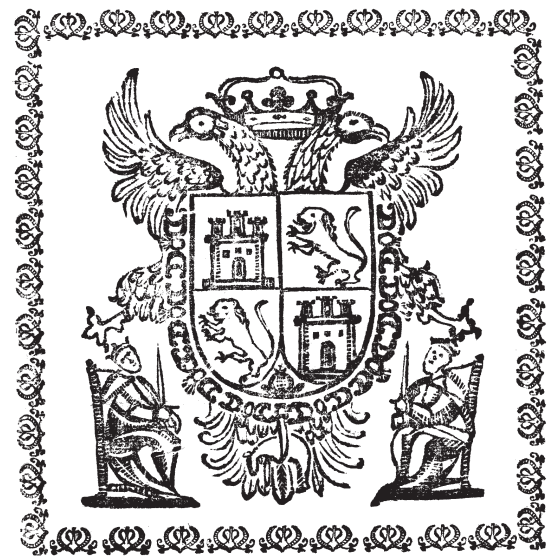

En Toledo: Por Aguitin de Salas Zaço,I mpreffor del Rey N.S. Año de 680 .

Imagen 2. Portada del impreso Moderación de precios... (1680)

El papel del ayuntamiento toledano en el establecimiento de los precios, no solo de los alimentos, durante el siglo XVII fue dado a conocer por J. Porres ${ }^{57}$ al extractar un interesante folleto intitulado Moderación de precios... ${ }^{58}$ que fue publicado en Toledo, en 1680, como consecuencia de una Real Provisión de 20 de julio de ese año dirigida a todas las justicias de los reinos para "arreglar los precios de todos los géneros a lo justo y raçonable". Pero de todas esas "justicias" solo conocemos lo actuado en las ciudades de Toledo y, curiosamente, Segovia, al haber sido difundido en sendos impresos ${ }^{59}$. Pero en ellos tienen cabida productos manufacturados, no alimentos.

defendida en la Universidad Complutense de Madrid en 2015. En su tesis maneja, entre otros documentos, expedientes de arrendamiento del suministro de pescado y de vino mediante el sistema de obligados conservados en el AMT. Una primera publicación de su esfuerzo lleva por título "Prices in Toledo, 1521-1650", y fue presentada en la 41st annual conference of the Social Science History Association, celebrada entre los días $17 \mathrm{y}$ 20 de noviembre de 2016 en Chicago (USA).

57 Porres Martín-Cleto, J.: "Política monetaria y precios en 1680: El caso de Toledo", Hacienda Pública Española, 87 (1984), pp. 185-197.

58 Moderación de precios de todos géneros comerciables, hecha en virtud de Real Provisión de su Magestad, y señores de su real Consejo, por la Imperial Ciudad de Toledo. Año de 1680, en Toledo, por Agustín de Salas Zaço, Impressor del Rey N.S., Año de 1680. Un ejemplar de este impreso, acompañado de los documentos originales que le sirvieron de antecedente formando un cuaderno, se conserva en AMT, Fondo Histórico, caja 54. Existe otro ejemplar en la Colección de Luis Alba, también en el AMT.

59 Tassa general y moderación de precios de todos géneros de mantenimientos, y otras cosas: hecha en virtud de Real Prouision de su Magestad, y Señores de su Real Consejo por la muy Noble Ciudad de Segovia, en 
La utilización de los libros de cuentas de los hospitales, y los de los conventos y monasterios, ha sido lo más habitual en España para el estudio de los precios en la Edad Moderna. Su importancia no suscita dudas ${ }^{60}$. Pero recordemos que en ellos solo están los productos adquiridos en días concretos conforme a los intereses y necesidades de esos centros, no todos los que se comercializaban diariamente en las ciudades. Además recogen los valores que expresan sus administradores y contables pero no tenemos seguridad de que esos precios fueran los reales. Resumiendo, en esa fuente documental, los libros de cuentas de hospitales y de conventos, no están todos los productos que podían adquirirse en el mercado, ni tenemos seguridad de que sus precios sean los oficiales, al margen de otros cuestionamientos ${ }^{61}$.

En páginas anteriores hemos puesto de manifiesto que los fieles ejecutores, o como fueran denominados en las principales localidades, se encargaron de establecer las posturas de los mantenimientos y que éstas quedaban reflejadas en determinados documentos expuestos en lugares muy visibles junto a los puntos de venta a manera de "lista de precios". El comprador sabía cuánto le iban a cobrar por lo que adquiría y nada podía venderse al por menor en los puestos públicos sin recibir "postura". Los libros de penas y condenaciones toledanos de los que hemos hablado dan cuenta de esas situaciones.

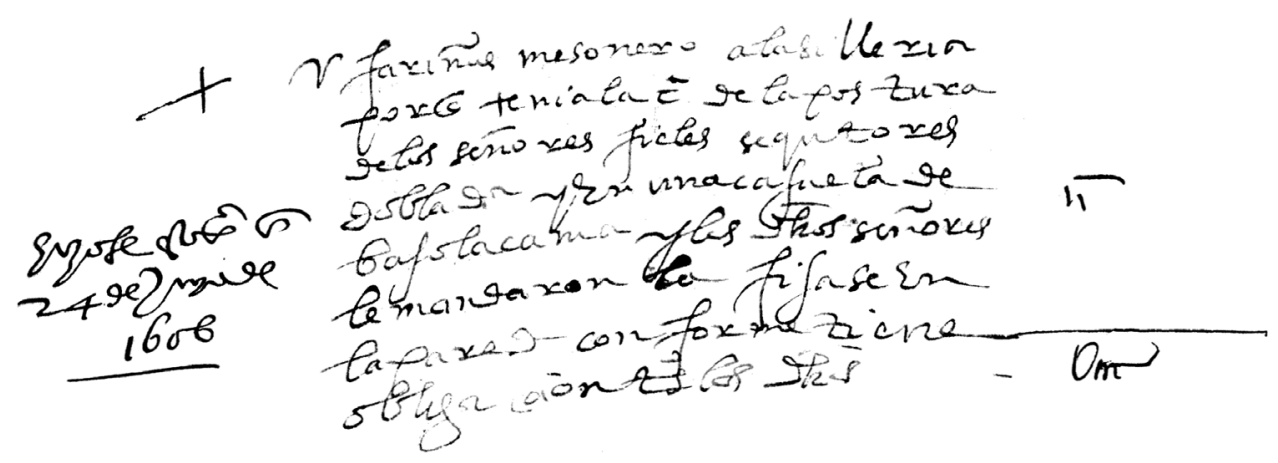

Imagen 3. Asiento de imposición de pena por el Juzgado de Fieles. 1606-06-24.

AMT, libro núm. $462^{62}$

Desconocemos tanto el motivo como la fecha concreta por los que el ayuntamiento de Toledo decidió dar un paso más en ese control al establecer que las posturas quedaran reflejadas en libros registro. Hasta entonces, los fieles ejecutores, merced al sistema establecido de rotación, conocían los precios que habían establecido, por

Madrid, en la Oficina de Melchor Alvarez, 1680. Muy posiblemente el ejemplo de Toledo fue imitado por el ayuntamiento segoviano. La existencia en el Archivo Municipal de Segovia de un ejemplar de la Moderación de los precios... nos lleva a esta conclusión.

60 En la actualidad, las cuentas de hospitales, colegios y otras instituciones benéficas siguen siendo la base fundamental para trazar series de precios de alimentos en la España Moderna. Así lo manifiestan los autores del artículo "Índices de precios de tres ciudades españolas, 1680-1800: Palencia, Madrid y Sevilla", América Latina en la Historia Económica, 32 (2009) pp. 29-80.

${ }_{61}$ ANES, G.: op. cit (nota 1) pp. 69-72.

62 En concreto en este asiento se indica: "fariñas, mesonero a la sillería, porque tenía la cédula de la postura de los señores fieles sequtores doblada y en una cajuela debajo la cama y los dichos señores le mandaron la fijase en la pared conforme tiene obligación, testigos los dichos". 


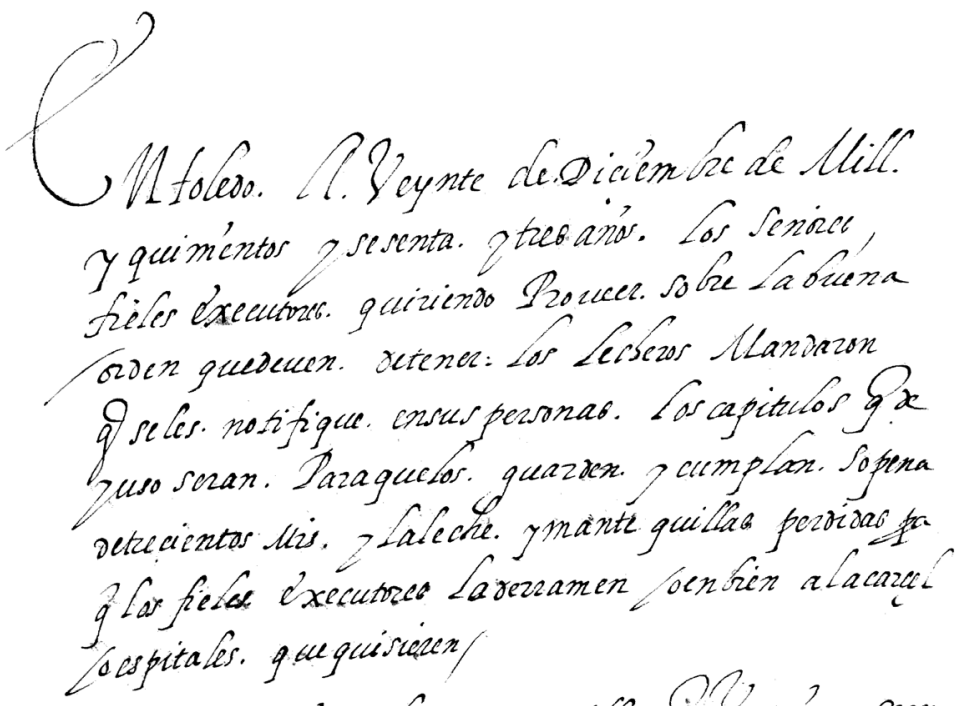

1. Arimeza uente" quefas uanteguizar ig Penvièren sem

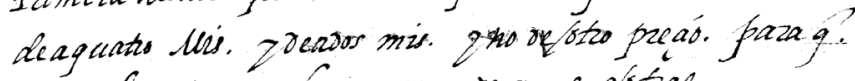
sevea clazamente. Logue va desnas ártias

1 ytengue sialgun particular. Yuisiene afgunas man teguilas depriao selas puevan bacen asemoderen

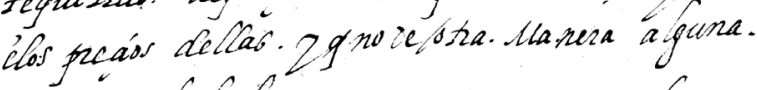
y ton guefaseche. vensan carayn. acumbe quesea poros natar. a veynte z güato lins. Logualtengan. enparte Publica Para quetoctos vean quelabiona $\hat{e}$ che. esia. Io jesnatar.

a ten. guefalecke desnatasa deguese bacen fas richas manteguilas. La rensan. casa on a cumber aroce libs ensustazes reposil. apartaro deb stos ga quevors

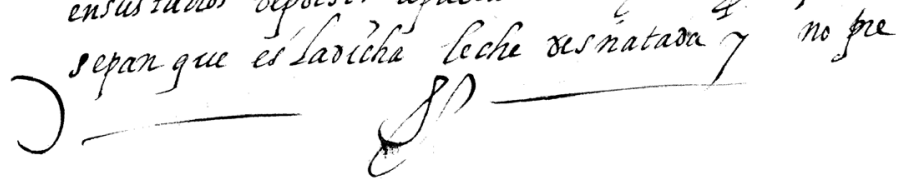

Imagen 4. Pregón sobre el precio de la mantequilla y la leche. 1563.

AMT, caja 1153.

lo menos en los días precedentes, al compartir esos datos entre ellos en sus reuniones matutinas. Unos los habían establecido mediante bandos o pregones, cuyo contenido textual conservaban sus escribanos, pero otros los habían dado en cédulas entregadas a cada vendedor sin que quedara un reflejo documental expreso en poder de los fieles. Un registro que contuviera por escrito todas las posturas, o casi, era un mecanismo muy eficaz para evitar fraudes porque recogía todas sus decisiones en un 
periodo amplio y, por lo tanto, las podían contrastar y estudiar. Es factible pensar que antes del establecimiento de estos registros existiera algún tipo de documento que contuviera esa información pero de forma más dispersa e imprecisa. Lo cierto es que los bandos o pregones relacionados con los mantenimientos nos aportan información sobre los precios aprobados en los siglos XVI y XVII. Pero son documentos emitidos que nacen para ser difundidos entre el público. No ocurre lo mismo con los libros registro de posturas, de los que vamos a tratar ahora, porque fueron elaborados para el uso interno de los fieles ejecutores, como prueba y garantía de sus decisiones en materia de precios. Y, lo cierto, es que por entonces también se empezaron a utilizar en Madrid ${ }^{63}$.

En la actualidad se custodian en el Archivo Municipal de Toledo un total de veinticinco libros de posturas de mantenimientos ${ }^{64}$ que abarcan un amplio periodo que va de 1659 a 1813 , aunque existen lagunas entre esas fechas ${ }^{65}$. La mayoría de ellos carecen de título. En los que tienen algún tipo de denominación, en su cubierta de pergamino o en su primera hoja interior de papel, predomina la de "Libro de posturas del Juzgado" o "Libro del Juzgado".

En concreto los libros conservados, con sus signaturas actuales y su extensión, ordenados por sus fechas, son los siguientes:

\begin{tabular}{|c|c|c|}
\hline Signatura & Fechas tope de las posturas & Número de hojas \\
\hline $585 \mathrm{~A}$ & $1659-09-26 / 1663-09-20$ & 48 \\
\hline 541 & $1663-10-04 / 1668-01-20$ & 78 \\
\hline $585 \mathrm{~B}$ & $1668-01-27 / 1670-12-24$ & 48 \\
\hline 586 & $1671-01-06 / 1675-02-17$ & 76 \\
\hline 587 & $1676-07-19 / 1679-10-29$ & 34 \\
\hline $588 \mathrm{~A}$ & $1680-09-14 / 1689-02-22$ & 123 \\
\hline $588 \mathrm{~B}$ & $1689-04-17 / 1700-12-23$ & 172 \\
\hline 589 & $1701-09-09 / 1708-06-24$ & 62 \\
\hline 590 & $1709-06-17 / 1721-06-21$ & 117 \\
\hline 591 & $1722-06-02 / 1729-01-09$ & 77 \\
\hline 592 & $1729-03-02 / 1735-11-27$ & 87 \\
\hline 593 & $1736-02-17 / 1741-11-21$ & 63 \\
\hline 594 & $1742-02-15 / 1744-06-23$ & 35 \\
\hline 579 & $1751-02-09 / 1754-06-08$ & 64 \\
\hline 596 & $1765-03-05 / 1767-07-14$ & 82 \\
\hline 597 & $1771-08-15 / 1774-05-20$ & 112 \\
\hline 598 & $1777-03-01 / 1783-01-31$ & 172 \\
\hline 599 & $1784-01-10 / 1788-02-18$ & \\
\hline
\end{tabular}

63 $\quad$ El primer libro de posturas madrileño conservado se inicia el $1^{\circ}$ de enero de 1654 y abarca hasta el 23 de diciembre de ese año. El primer producto que recibió postura fue la toronja en miel y el último las patatas. Véase AVM, Repeso Mayor, legajo 32, núm. 3.

64 Antonio Sierra Corella en su texto "El Archivo Municipal de Toledo..." (p. 704) indicaba que existían trece volúmenes de libros de posturas de los fieles ejecutores datados entre 1680 y 1808.

65 Nos faltan datos de los siguientes periodos: 1675-02-18/1676-07-18, 1679-10-30/1680-09-13, 1700-1224/1701-09-08, 1708-06-25/1709-06-26, 1721-06-22/1722-06-01, 1744-06-24/1751-02-18, 1754-06-09/176503-04, 1767-07-15/1771-08-14, 1774-05-21/1777-02-28, 1783-02-01/1784-01-09, 1794-12-02/1799-09-17, 1802-03-07/1808-08-17, y 1811-04-12/1812-09-22. La serie documental de libros de posturas conservada en el Archivo de Villa de Madrid es mucho más completa. 


\begin{tabular}{|c|c|c|}
\hline 600 & $1788-03-23 / 1791-06-07$ & 150 \\
\hline 601 & $1791-06-08 / 1793-01-07$ & 90 \\
\hline 602 & $1793-01-01 / 1794-12-01$ & 119 \\
\hline 603 & $1799-09-18 / 1802-03-06$ & 181 \\
\hline 604 & $1808-08-18 / 1811-04-11$ & 69 \\
\hline 785 & $1812-09-23 / 1813-07-02$ & 21 \\
\hline 786 & $1813-02-10 / 1813-05-30$ & 4 \\
\hline
\end{tabular}

Tabla 1.

Podemos comprobar que con ellos disponemos de información sobre los precios de los mantenimientos vendidos en Toledo en los años comprendidos entre 16591675, 1676-1744, 1751-1754, 1765-1767, 1771-1774, 1777-1794, 1799-1802, y 1808-1813. Es decir, durante más de 110 años. Y lo interesante es que durante ese amplio periodo no conservamos libros de penas y condenaciones, como sí los hay de 1529 a 1636, por lo que ambas series se complementan, aunque los libros de posturas ofrecen datos más precisos y claros sobre el valor en venta al por menor de los productos que llegaban al mercado toledano.

Nos resulta difícil poder cuantificar la cantidad de información ofrecida en estos libros porque no son uniformes en su contenido. Tan solo hemos extraído los datos de todas y cada una de las posturas recogidas en tres de ellos, comprendidos entre 1765 y 1783 , y los resultados no son parejos.

\begin{tabular}{|c|c|c|c|c|}
\hline Libro núm. & Fechas & $\begin{array}{c}\text { Número de } \\
\text { hojas }\end{array}$ & $\begin{array}{c}\text { Núm.de } \\
\text { posturas }\end{array}$ & Media por hoja \\
\hline 596 & $1765 / 1767$ & 82 & 1.355 & 16,5 \\
\hline 597 & $1771 / 1774$ & 86 & 3.232 & 37,5 \\
\hline 598 & $1777 / 1783$ & 112 & 8.469 & 75,6 \\
\hline
\end{tabular}

Tabla 2.

Teniendo en cuenta que los veinticinco libros de posturas están formados por un total de 2.170 hojas de tamaño folio, y elegimos la media de las cifras anteriores (37,5 posturas por hoja), podemos presuponer que en ellos existen más de 80.000 referencias de precios de alimentos entre 1659 y 1813 . Pero la información que contienen unos y otros ofrece variaciones.

El primero conservado contiene asientos desde finales de 1659 e incluye en su primera hoja, a manera de título, el siguiente texto manuscrito: "Libro donde los $\mathrm{s}$ [eñor] es fieles executores asientan las posturas de los mantenimientos que vienen a esta ciudad de Toledo de la mano y pluma de D. Juan López y Recas". De este último sabemos que era miembro del cabildo de jurados y que, como tal, debió desempeñar por dos meses ese cargo de fiel ejecutor. Lo cierto es que en sus 48 hojas contiene asientos entre el 26 de septiembre de 1659 y 20 de septiembre de 1663, es decir durante cuatro años, por lo que, iniciado tal vez por él, sirvió para que otros fieles anotaran posturas durante todo ese tiempo. Es un libro realizado por ellos, sin presencia de escribanos municipales, y redactado sobre papel sellado. Las posturas sucesivas parecen estar anotadas por manos diferentes pues eran escritas en el libro, indistintamente, por los fieles intervinientes, de su puño y letra. Tras cada postura figuran las 
firmas autógrafas de las personas que las han acordado, precedidas de textos como el que sigue "En la ciudad de Toledo en [día y mes] se juntaron los señores fieles ejecutores para hacer las posturas siguientes". Tras incluir los precios pueden terminar con frases del tipo "Y a dichos precios se vendan y no a más. Y lo firmaron". Pero, ya bien entrado el siglo XVIII, predominan anotaciones aún más simples, que solo contienen la denominación de los artículos comercializados con sus precios, junto con alguna rúbrica de los fieles que los aprueban.

Del año 1660, primero del que se tienen datos completos, se incluyen cuarenta y cinco acuerdos de los fieles que recogen distintas posturas. Algunas pueden tratar de un solo producto, pero las hay en que se da precio a diez o más de esos alimentos, lo que solía ocurrir con los pescados, los productos de confitería y los derivados cárnicos. De estos últimos, por ejemplo, trata el acuerdo de 23 de noviembre de 1659 en el que recibieron postura el tocino fresco, el solomo de tocino, la manteca, el solomo adobado, las salchichas, las morcillas, las pajarillas (bazo), el pie y mano de lechón, la asadura y el hocico. El 16 de octubre de 1660 se estableció el precio en venta al por menor de los bizcochos, el azúcar de pilón, el calabazate, el diacitrón, los canelones, las grajeas, las almendras, los garbanzos, el arroz, las lentejas, las pasas de sol y de lejía, los orejones, los dátiles y otros productos que se vendían en las confiterías. Ahora bien, más de la mitad de las posturas aprobadas en 1660 están relacionadas con la venta de pescado, especialmente los martes, día de mercado. Este pescado llega casi siempre seco, es decir curado al aire (a veces en salazón), o en escabeche, aunque también se vendía fresco procedente del río Tajo. En las posturas se da cuenta de la venta en Toledo de salmón, sábalo, atún, albur (mújol), mielga, pulpo, truchuela (bacalao), arenque, sardina, congrio, besugo, boga... ${ }^{66}$

Los acuerdos de posturas suelen producirse casi siempre los martes, al menos en estos primeros años (1659-1663). Muy posiblemente, por entonces, solo se anotaban algunas de las posturas, las más relevantes porque entendemos que hay productos que llegaban al mercado y no están reflejados. Ocurre, por ejemplo, con las aves, los conejos, los huevos, las frutas o las verduras cuyas posturas sí serían recogidas ampliamente en el siglo XVIII. De estas últimas tan solo se mencionan en ese primer libro y de forma esporádica los "manojos de bretones" ${ }^{6}$, las espinacas y las acelgas.

Sí tienen cabida en estos registros, desde los primeros conservados, algunos productos que tenían un comercio reducido o muy estacional como ocurría con el turrón $^{68}$ y otros alimentos propios de las fiestas de Navidad (castañas, nueces, piñones y avellanas), las especias (azafrán ${ }^{69}$, cilantro, comino, alcaravea, anís, alhucema y orégano), los quesos, el jabón, el aceite (por panillas o libras) o el vino añejo.

Entendemos que conforme van pasando los años en estos libros se empieza a

${ }_{66}$ El primer libro de posturas conservado, iniciado en 1659 (Libro núm 585A), comienza con una "Memoria que se a sacado de las hordenanças de la ziudad del peso que toman los pescados secos después de hechados en agua por donde se debe reconocer como se an de hacer las posturas". En ella se recogen frases como "La libra de atún de yjada toma después de agua dos onças y quarta". Al final aparece que "El celemín de los garvanços después de agua pesa veinte libras".

67 El bretón es una variedad de la col.

68 En el arancel aprobado por los fieles ejecutores de Madrid para el $1^{\circ}$ de diciembre de 1766 hay un apartado específico para el turrón en el que se distinguen doce tipos con precios diferentes. Véase AVM, Repeso Mayor, legajo 42, núm. 2.

69 El 25 de octubre de 1660 los fieles acordaron que la onza de azafrán se vendiera a cuatro reales. Ya entonces era una de las especias más apreciadas y caras. A finales del siglo XVIII la onza llegó a venderse en Toledo a nueve reales. 
280

García Ruipérez, M. Cuad. hist. mod. 42(1) 2017: 261-290

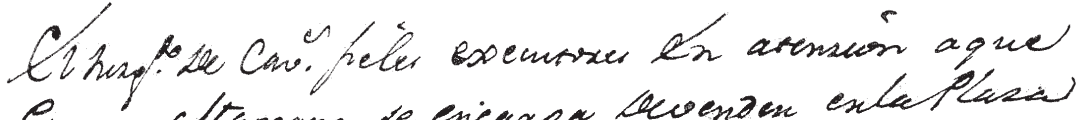

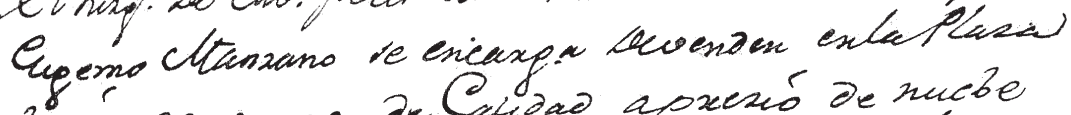
havor paxansos de Calidad apxesió de nucbe

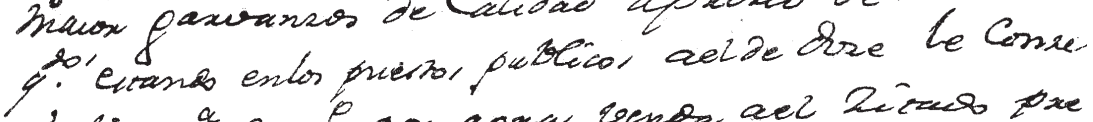

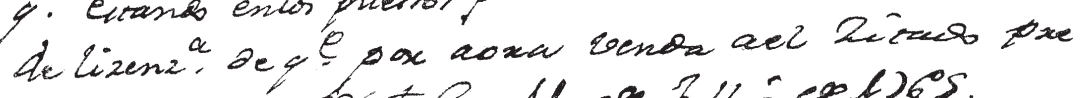

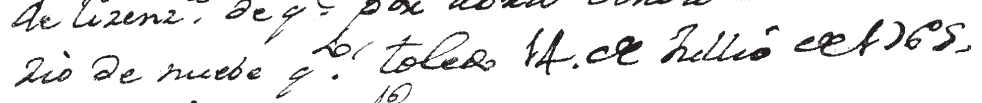

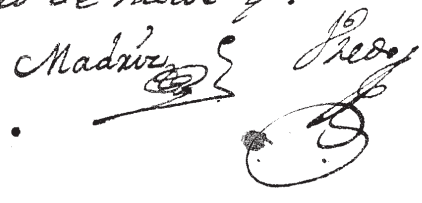

Oy 14.0 hilio

tomace a 4.4 : Lexuclia of fiox a 3 ,

2 Zuesar De picion a 4 .

Humone $a$...... 4

C.5 17.

Bubar neprar a $3 \dot{0}$

Pexar de ku panizla 3.50

oyts. at atho.

$$
\begin{aligned}
& \text { Losiar a } 4 \\
& \text { terniater as } 4 \\
& \text { Betenvirace a } 6 \\
& \text { Pepin } 15
\end{aligned}
$$

Mastes 16

Inovarade.

Zizucian de flox $=3$ to Afor a $4 q^{\text {tor }}$

- …

otsderintio tho

Aurm dila 2lava $14 g^{\text {to }}$.

detumes- . $12 g^{t 00}$

Juviar-3t

Bexingar

Ppinos a ceirma.

Aprayer as $g^{\circ}$.

- Juáóa lamí

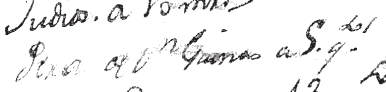

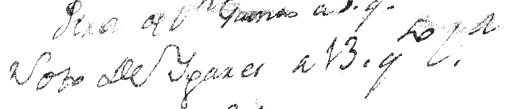

Guloos a $209^{\circ}$

- Zuciar ab a -

Bexengenar a 4 .

Pecinor a 1 .

Praprear réna ?

Leviar sepico.atón fos

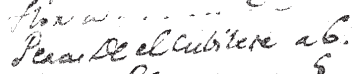
detoriunso 5 .

cyipo a

\&.

Imagen 5. Posturas realizadas por el Juzgado de Fieles Ejecutores entre el 14 y el 19 de julio de 1765. AMT, libro núm. 596

recoger una información más completa y variada. Y de ello da prueba el contenido de los conservados de finales del siglo XVIII que hemos analizado. Es factible pensar que las anotaciones en estos registros dependían del rigor de los fieles de turno que, como sabemos, desempeñaban sus cargos durante dos meses. También influía la estacionalidad de los productos alimentarios que llegaban al mercado. La oferta 
era más variada en los meses de verano y en diciembre (por las fiestas de Navidad) y ello implicaba realizar más posturas.

Además, cuando el abastecimiento de un determinado producto recaía en un obligado dejaba de aparecer en los libros de posturas al no ser competencia de los fieles, pues el precio de ese artículo se establecía para todo el año por escritura pública. Así, en 1793, al principio del libro de posturas, se incluye una "razón de los precios de los abastos" rematados en obligados. El ayuntamiento de Toledo había llegado a acuerdos con distintas personas para que garantizaran el suministro durante todo un año de bacalao, velas de sebo, aceite, jabón, tocino, carnero, macho y vaca a unos precios prefijados ${ }^{70}$. Pero no todos los años hay obligados de esos productos. Y cuando no hay ningún abastecedor que monopolice el suministro, esos artículos llegan al mercado y los fieles deben ponerlos precio. De todas formas, en estos libros de posturas solo de forma esporádica se anotan los precios de lo que entendemos por productos alimenticios básicos como el pan, el vino, el aceite, el vinagre y la carne no elaborada. Y lo mismo ocurre con el carbón o el jabón. Para su estudio es preciso acudir a los expedientes de contratación de estos abastos, que casi siempre recaían en obligados, o a los propios libros de acuerdos municipales ${ }^{71}$.

También debemos de tener en cuenta que las coyunturas inflacionistas podían provocar cambios más continuos, como ocurrió a finales del siglo XVIII. Un periodo de estabilidad económica implicaba que no hubiera alteraciones en el precio por lo que no era necesario modificar posturas aprobadas tiempo atrás. Los factores son, pues, muchos y complejos.

El día de la semana en el que más mantenimientos se ofrecen en venta en el mercado toledano es el martes, pero eso no es óbice para que las posturas se produzcan en otras fechas. Y en ello hay grandes contrastes. De 1766, por poner como ejemplo un año muy interesante por los motines de subsistencia, se recogen 369 posturas en el libro correspondiente ${ }^{72}$. No hay ninguna del mes de noviembre y solo cuatro del mes de enero. Por el contrario se asentaron 87 en el mes de julio, dadas en 22 días distintos. En 1778 no hay tantas oscilaciones. Se registraron ese año 1.505 posturas, con valores extremos que van de 52 en el mes de mayo a 156 en el mes de noviembre. Estas últimas se distribuyen en 23 de sus días, pero prácticamente la mitad (79) fueron fijadas en los cuatro martes de ese mes $(3,10,17$ y 24$)$, que como sabemos era, desde 1465 , el día en que se celebraba el mercado franco ${ }^{73}$.

La variedad de productos que registran los libros de posturas toledanos es muy grande. Además en bastantes ocasiones al dato concreto del precio se añade el de su procedencia lo que nos da idea de una red de transporte muy extensa. Basta ahora decir que en Toledo se vendieron barriles de ostras el 11 de marzo de 1781 a 9 reales,

70 Por ejemplo, en el abasto del tocino del año 1793 aparece la siguiente frase: "Remató en Prudencio Redondo, vecino del lugar de Mozejón, obligándose a dar cada livra, todo el mes de Abril a 19 quartos; y lo restante del año que principia el Sábado Santo del corriente y cumplirá el Viernes Santo del que viene a 20 quartos". Véase AMT, libro núm. 602.

71 Sobre el papel de los obligados en el abasto de Toledo en los siglos XVI y XVII remitimos a la obra de J. Montemayor, Tolède entre fortune et déclin (1530-1640), Limoges, Pulim, 1996, especialmente las pp. $72-86$. Y para León es muy útil el texto de R. Cubillo de la Puente y C. Méndez Méndez, "Alimentación: comercio y abastecimiento. Un peculiar comercio: el sistema de obligación y los obligados; distribución, comercio y consumo de alimentos", en La historia de León, Vol. 3, León, Universidad de León, 1999, pp. 429-444.

72 En el AVM, en su Fondo de Repeso Mayor, también se conservan los libros de posturas de ese año, en concreto en su legajo 42, números 5 (libro de 1765-1766) y 2 (libro de 1766-1767).

73 Lorente Toledo, L.: "Privilegios de concesión y confirmación de un mercado franco, el martes, a la ciudad de Toledo (1465-1475). Estudio y edición”, Anales Toledanos, XXIV (1987), pp. 31-39. 
el 5 de febrero de 1782 a 6 reales y el 14 de enero de 1783 a 7 reales.

El pernil (jamón) se vendía dos o tres veces al año en el mercado con precios que oscilaban, cada libra, entre los 17 cuartos ( 2 reales) y los 25,5 cuartos (3 reales), entre 1765 y 1782; y sobre su origen, los libros nos señalan casi siempre Extremadura, a veces con lugares concretos como Cabezuela, Candelaria y Montánchez. También llegan "perniles dulces" de Galicia.

El tamaño de los productos implicaba variaciones en su precio, especialmente cuando se venden por piezas y no por libras. Es el caso de las granadas, vendidas casi siempre por piezas o docenas, y que procedían "de la tierra", es decir, de pueblos cercanos a Toledo como Cebolla, Mesegar o Recas, y sobre todo de Murcia. Las posturas son diferentes según fueran "gordas", "grandes", "medianas", "chicas", "pequeñas", "dulces", "buenas"... (de todas estas formas son calificadas en los libros analizados). Otras veces se las define con la ayuda de adjetivos que reflejan variedades, origen o calidades. El ejemplo más llamativo pueden representarlo las ciruelas. En las posturas se mencionan las ciruelas de frutilla, de flor, de yema o de reina. También hay ciruelas diaprea, cascabelillos, chabacanas, comunes, melares, verdales, sevillanas e, incluso, ciruelas de San Juan o ciruelas pasas.

Las fluctuaciones estacionales en los precios, relacionadas con la oferta y la demanda, son fáciles de estudiar con determinados productos de amplio consumo. Un ejemplo llamativo lo pueden representar los tomates. En el año de 1766 los primeros que se vendieron en Toledo, el 17 de julio, alcanzaron el precio de 10 cuartos por libra (40 maravedís). En los días sucesivos el descenso en su valor es vertiginoso al aumentar la oferta. Así el día 19 de julio se encuentran tomates a $32 \mathrm{mrs}$. la libra, el 21 a 24 mrs., el 24 a 16 maravedíes. Y entre el 25 de julio y el 7 de agosto cada libra de tomate cuesta en el mercado toledano 8 maravedíes. Este último día empieza a comercializarse a $6 \mathrm{mrs}$. A este precio se mantendrá hasta el 2 de septiembre, fecha en la que una nueva bajada sitúa su valor en 4 maravedíes. Hasta el día 24 de octubre no volverá a subir, vendiéndose la libra de los últimos de la temporada a $6 \mathrm{mrs}$. Es decir, en apenas unos meses de 1766, el precio de la libra de tomate osciló en la ciudad de Toledo entre los 40 y los 4 mrs. En 1782, solo se comercializaron tomates a este último precio entre el 19 de septiembre y el 14 de octubre con la particularidad de que los primeros que pudieron ser adquiridos lo fueron el 29 de mayo a 68 maravedíes la libra. Los trajeron desde Valencia. La siguiente partida de tomates no llegaría a Toledo hasta el 17 de julio desde la localidad de La Puebla de Montalbán alcanzando un valor de 40 maravedíes.

Más variedad, en cuanto a su origen, reflejan estos libros al referirse a las patatas. Sabemos que proceden casi siempre de La Mancha ("patatas manchegas"), es decir de pueblos situados mayoritariamente en la actual provincia de Ciudad Real, caso de Almagro, pero también hay partidas que llegan desde la comarca de La Vera, El Barco (Ávila), Galicia e, incluso, Málaga ${ }^{74}$. Su presencia en el mercado toledano es bastante habitual si nos detenemos en los libros de posturas que hemos analizado detenidamente (1765-1783). Las primeras patatas de cada cosecha se venden casi siempre a finales de octubre o principios de noviembre de cada año y pueden adquirirse en el mercado hasta marzo o abril del año siguiente. La postura más alta que hemos encontrado se da el 14 de febrero de 1766 con un precio de 6 cuartos (24 mrs.)

En el arancel de precios de Madrid, de 1 de diciembre de 1766, figura el de las "batatas de Málaga en dulce". Es posible que lo que llega a Toledo sea este producto y no patatas. Véase AVM, Repeso Mayor, legajo 42, núm. 5. 
la libra pero lo normal es que en los meses de enero y febrero se pueda adquirir, cada libra, entre los 10 y los $14 \mathrm{mrs}$. No se detectan las grandes oscilaciones comentadas en cuanto al tomate, sin duda porque la patata no se producía en zonas cercanas a Toledo y podía ser transportada y conservada mejor que esa baya.

De todas formas, estas variaciones son menos perceptibles en alimentos que pueden llegar al mercado durante todo el año, o casi, y que no dependen de los cambios climáticos. Sería el caso de los pescados procedentes del mar. Pongamos como ejemplo el atún. A Toledo llegaba desde los puertos pesqueros, tras su correspondiente secado, aunque también se comercializaba en escabeche, principalmente lo que en los libros de posturas se denomina como "atún de ijada" (ventresca), que era el más valorado, junto con el "atún del tronco". El precio de este último era 3 o 4 cuartos inferior por libra al primero. Dentro del atún de ijada también había diferencias si procedía de un atún de "bajada" o "venida", o de "subida" o "retorno", en clara referencia a sus migraciones anuales. El que alcanzaba un mayor precio era el primero, es decir, el atún de ijada de bajada o venida, cotizándose la libra entre dos y cuatro cuartos ( 8 y 16 mrs.) más caro que el de subida. En 1782 se vendió la libra de ventresca de atún de bajada a 24 cuartos el 12 de febrero, a 22 el 31 de mayo y a 24 el 17 de septiembre. Ahora bien, una partida de atún de ijada de Cerdeña alcanzó el precio de 32 cuartos $^{75}$ el 28 de octubre de ese mismo año.

Otro pescado del mar vendido en Toledo es el congrio. En los libros de posturas se nos indican tres procedencias distintas: Vizcaya, Laredo y Muros, por lo que entendemos que se enviaban desde localidades situadas a lo largo de toda la cornisa cantábrica. Lo interesante es que en nuestra ciudad llega casi siempre "fresco", no seco, al igual que ocurría en Madrid ${ }^{76}$. Una libra de congrio fresco costaba entre 4 y 6 cuartos más barata que la de seco. Entre 1772 y 1782 su precio osciló entre los 76 y 120 mrs., la libra. En esos años, solo se vendió en el mercado toledano en los meses de invierno (de noviembre a abril).

Con los ejemplos que acabamos de recoger entendemos que hemos dado una idea aproximada del contenido de estos libros de posturas. Los productos comercializados en el mercado ofrecen ligeras variaciones unos años con respecto a otros. Basta ahora decir, utilizando el del año 1766 como ejemplo, que incluye datos de precios de cerca de un centenar de "mantenimientos". Así, entre las frutas hay información del valor en el mercado toledano de los melocotones, albaricoques, manzanas, peras, peros, ciruelas, guindas, cerezas, granadas, limas, limones, membrillos, camuesas, endrinas, nueces, castañas, piñones, aceitunas, higos, brevas, melones y sandías. Entre las hortalizas, legumbres, tubérculos y similares encontramos las cebollas, los ajos, las zanahorias, las patatas, los pimientos, los espárragos, las habas, los guisantes, los pepinos, las berenjenas, los nabos o las judías. Como especias destacamos la presencia ese año del azafrán, las criadillas de tierra (trufas), las alcaparras, los cominos, el cilantro, el anís, el orégano, la alhucema (espliego) o la alcaravea. Además de "peces del Tajo" los toledanos pudieron adquirir, en sus plazas, merluzas, carpas, atunes, anguilas, barbos, truchas, bonitos, melvas, abadejos, salmones, besu-

Recordemos que 32 cuartos equivalen a 128 maravedís, o lo que es lo mismo a 3 reales y 26 maravedíes.

76 En Madrid, los pescados que se solían vender "frescos" eran el congrio y el besugo. Desde Laredo se tardaban unos seis días en transportar los congrios hasta la Corte. A Toledo les costaría un día más, al menos. A finales del siglo XVIII un 30\% del pescado que se vende en Madrid es "fresco". Véase Bernardos Sanz, J.U.: "El abastecimiento y consumo de pescado en Madrid durante el Antiguo Régimen", en VII Congreso de la Asociación de Historia Económica, Zaragoza, Asociación de Historia Económica, 2002. 


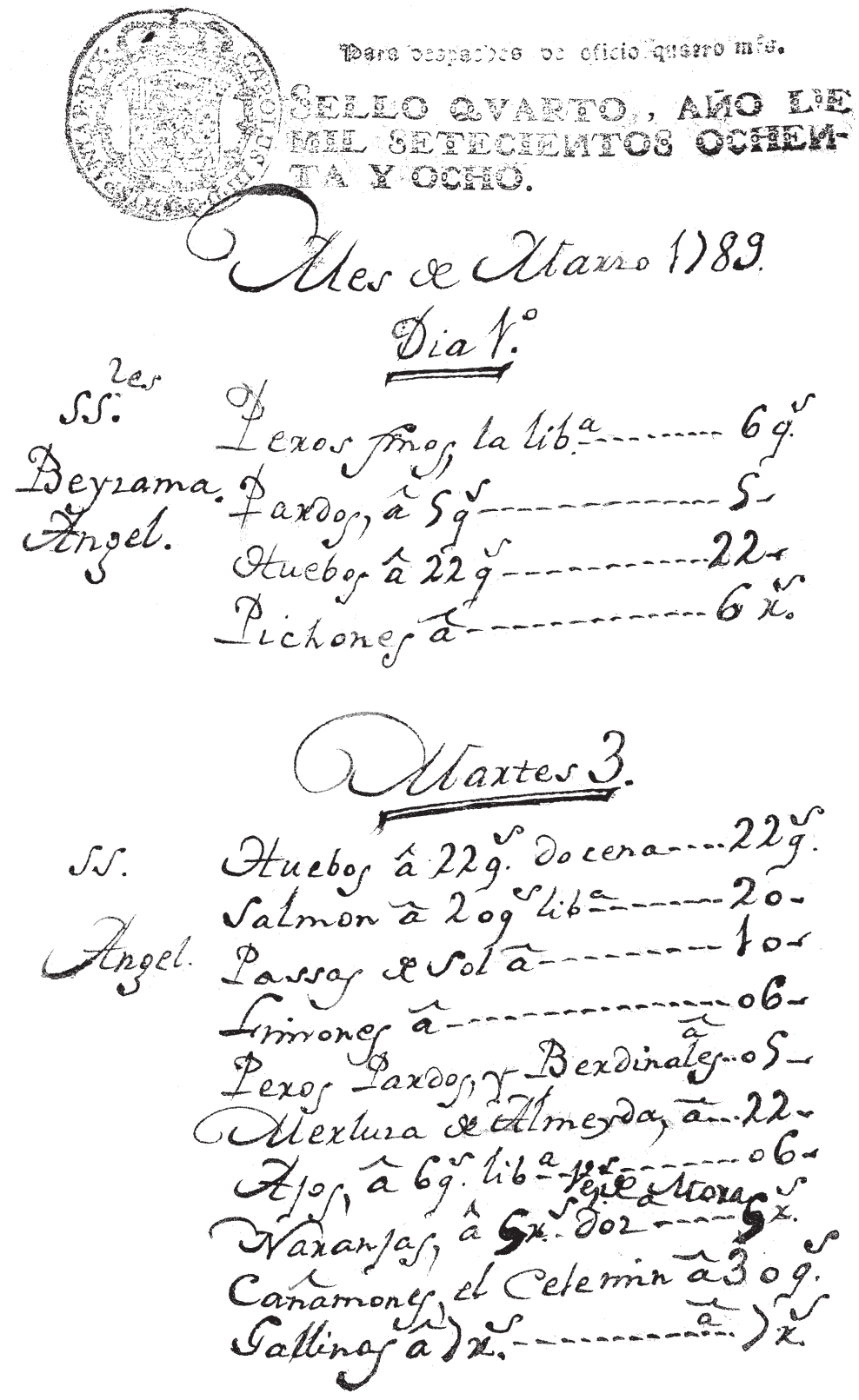

Imagen 6. Posturas realizadas por el Juzgado de Fieles Ejecutores entre los días 1 y 3 de marzo de 1789. AMT, libro núm. 600.

gos y congrios. Entre los derivados cárnicos recibieron postura los lomos adobados, los chorizos, los perniles, los tocinos, las mantecas, las salchichas, las longanizas... También se vendieron todo tipo de quesos de oveja y de cabra, názula (requesón), leche, huevos, gallinas, capones, perdices, conejos, pichones... junto con turrones, tendidos de alegría y otros artículos de confitería. Incluso se puso precio al acemite (salvado), las "manadas de verde", las velas... 


\section{Los aranceles de vendedores y de tiendas}

La actividad del Juzgado de Fieles Ejecutores toledanos, en relación con los precios de los alimentos, no solo puede examinarse con los registros analizados de "penas y condenaciones" y de "posturas de mantenimientos" pues también es preciso consultar la serie de aranceles ${ }^{77}$, la mayoría impresos (aunque también los hay totalmente manuscritos), que este tribunal aprobó entre finales del siglo XVII y principios del XIX. Los hay generales y, también, específicos de tiendas concretas ${ }^{78}$.

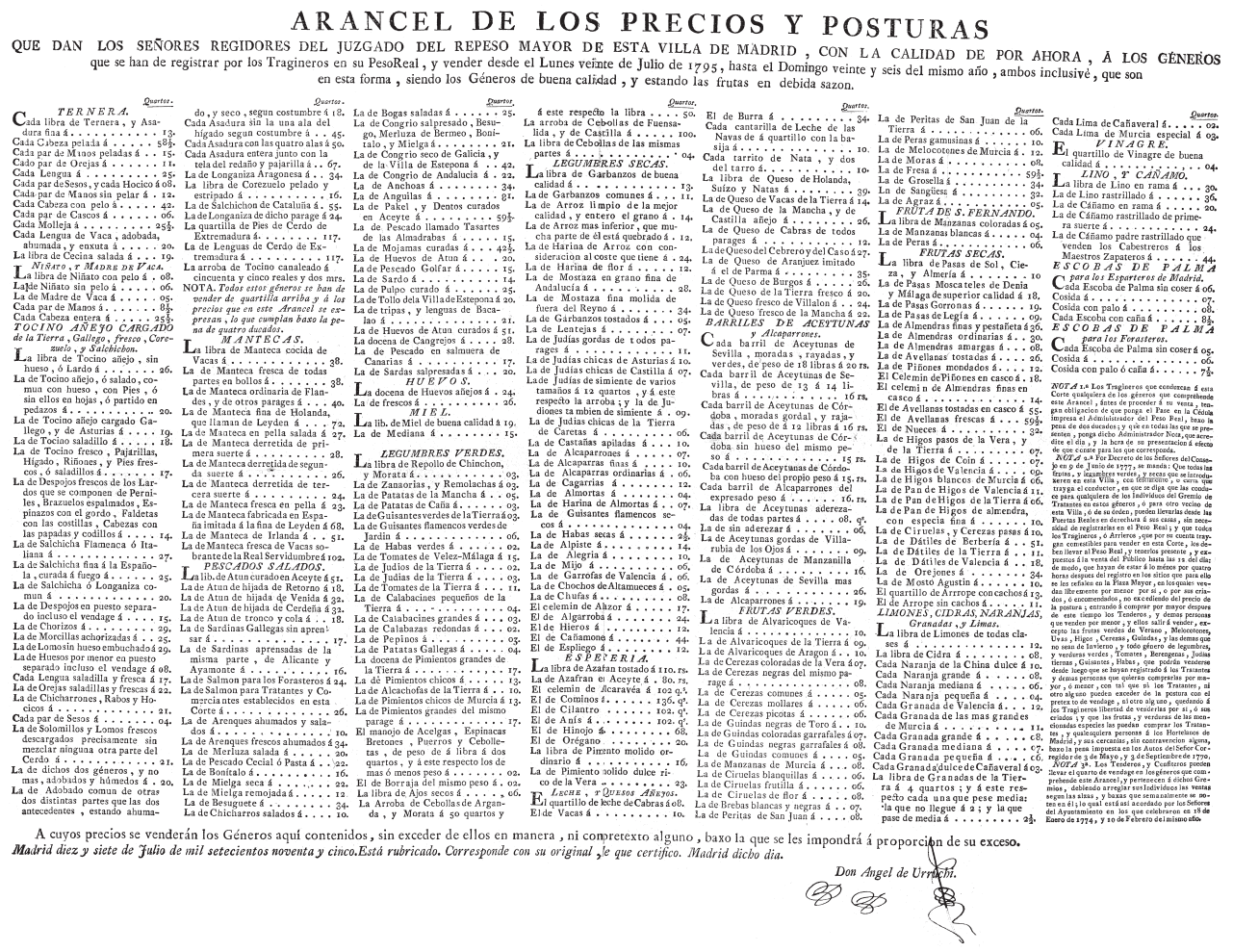

Imagen 7. Arancel general de los precios y posturas de Madrid para la semana del 20 al 26 de julio de 1795.

Los primeros, los generales o "aranceles de vendedores", recogen todos los "mantenimientos" que se podían adquirir en las plazas públicas toledanas a finales del siglo XVIII, dejando en ellos sin anotar el precio de los productos no comercializados en cada ocasión. Es decir, servían a manera de plantilla para un periodo muy amplio aunque los precios que en ellos se recogían, casi siempre de forma manuscrita, variaran cada día de mercado. En Madrid a finales del siglo XVIII se aprobaban e

77 En el Diccionario de Autoridades (Tomo I, Madrid, Imprenta de Francisco del Hierro, 1726, p. 369) se define "Arancel", como el "Decreto o ley a modo de tarifa, que pone tassa, y determina los derechos de los Ministros de Justicia; lo que deben de pagar los géneros en las Aduanas, y el precio en que se han de vender las cosas". Este último es su significado en este contexto.

78 Estos aranceles se conservan en la actualidad en las cajas 55 y 55 Bis del Fondo Histórico del AMT. 
imprimían cada semana. Con anterioridad el sistema era diferente ya que lo habitual había sido entregar la "cédula de la postura"79 individualizada a cada vendedor, diferenciando su contenido según los productos que ofrecían. Y esta cédula es la que ellos colocaban junto a su puesto.

\begin{tabular}{|c|c|}
\hline Toledo & de 176 \\
\hline $\begin{array}{l}\text { Ajos, à } \\
\text { Ciebollas, à } \\
\text { Piñones, à } \\
\text { Caftañas, à } \\
\text { I gos blancos fecos, à } \\
\text { I gos negros fecos, à } \\
\text { INuezes, à } \\
\text { Bellotas, à } \\
\text { Granadas, à } \\
\text { Pimiento, à } \\
\text { Azeytunas, à } \\
\text { Cañamones, à } \\
\text { Quefo de Cabras, à } \\
\text { Quefode Ovejas, à }\end{array}$ & $\begin{array}{l}\text { uartos la libra. } \\
\text { quartos la libra. } \\
\text { quartos el celemin. } \\
\text { quartos el celemin. } \\
\text { quartos la libra. } \\
\text { quartos la libra. } \\
\text { quartos el celemin. } \\
\text { quartos el celemin. } \\
\text { quartos la docena. } \\
\text { quartos la libra. } \\
\text { quartos el celemin. } \\
\text { quartos el celemin. } \\
\text { quartos la libra. } \\
\text { quartos la libra. }\end{array}$ \\
\hline
\end{tabular}

De cuyos prècios no exceda, pena, que ferà caftigado à voluntad del Juzgado, teniendo efta de manifiefto, para que la lean con facilidad.

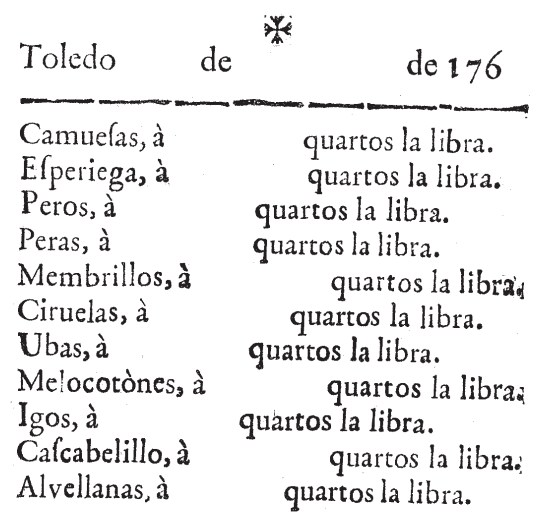

De cuyos prècios no exceda, pena, que ferà caftigado à voluntad del Juzgado, teniendo efta de manifiefto para que la lean con facilidad.

$\begin{array}{lc}\text { Toledo de } & \text { de } 176 \\ \begin{array}{l}\text { Verengenas, à } \\ \text { Tomates, à } \\ \text { Judias, à } \\ \text { Calabaza, à } \\ \text { Melones, à } \\ \text { Pepinos, à }\end{array} & \begin{array}{c}\text { quartos la docena. } \\ \text { quartos la libra. } \\ \text { quartos la libra: }\end{array} \\ \begin{array}{c}\text { quartos la libra. } \\ \text { quartos la libra. }\end{array}\end{array}$

De cuyos prècios no exceda, pena, que ferà caftigado à voluntad del Juzgado, teniendo efta de manifiefto para que la lean con facilidad.

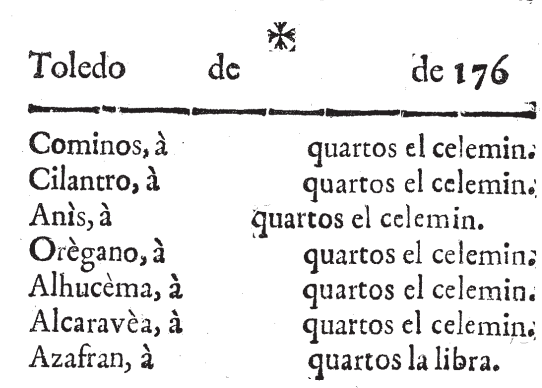

De cuyos prècios no exceda, pena, que ferà caltigado à voluntad del Juzgado, teniendo efta de manifiefto para que la lean con facilidad.

Imagen 8. Impreso con cédulas de postura sin cumplimentar utilizado en Toledo la década de 1760 .

\footnotetext{
79 Esta referencia a las "cédulas de la postura" aparece en un "Arancel que los señores corregidor y Toledo dan a las personas que recogen huéspedes y lo que han de llevar los huéspedes por la posada, y lo que han de hazer y guardar siendo tal mesonero, en el dicho mesón", fechado en el siglo XVII y conservado en la caja 55 Bis del AMT.
} 
Los aranceles específicos o "aranceles de tiendas" son aprobados y mandados imprimir por el Juzgado de Fieles de Toledo cada cierto tiempo (unas pocas veces al año). En ellos solo se recogen los productos concretos, con sus precios, que se vendían en las tiendas de abacería, confitería, pastelería y botillería. Cada tipo de tienda tenía su propio arancel. Los más numerosos, de entre los conservados, son los de confitería. Este documento, a manera de lista de precios, debía estar expuesto en la tienda en un sitio bien visible "en parte donde los que vayan a comprar lean con facilidad", porque si no era así podían sufrir severas multas. Su contenido a veces está recogido, también, de forma manuscrita en los libros de posturas, pero no siempre.

\begin{tabular}{|c|c|}
\hline NZEL DE TIEN & \\
\hline $\begin{array}{l}\text { Quefo añejo de Ovejas, à catorce quartos la libra. } \\
\text { Quefo frefco de Cabras, à feis quartos la libra. } \\
\text { Caftañas apiladas, à quatro quartos y medio la libra. } \\
\text { Higos negros de Valencia, à cinco quartos la libra. } \\
\text { Higos blancos, à quatro quartos la libra. } \\
\text { Garranzos, à nueve quartos la lıbra. } \\
\text { Garranzos remojados, à dos quartos la libra. } \\
\text { Paffas de Sol, à ocho quartos la libra. } \\
\text { Paffas de lexì, à frete quartos la libra. } \\
\text { Judias, à frete quartos la libra. } \\
\text { Lantejas, à quatro quartos la libra. } \\
\text { Arroz, à ocho quartos la libra. } \\
\text { Miel blanca, à doce quartos la libra. } \\
\text { Pimiento colorado, à doce quartos la libra. } \\
\text { Vinagre, à diez quartos la azumbre. } \\
\text { Algarrobas, à veinte y quatro quartos el celemin. } \\
\text { Cerezas paffas, à quatro quartos la libra. } \\
\text { Ciruelas de Cazorla, à quatro quartos la libra. } \\
\text { Paffas negras de racimo, à cinco quartos la libra. } \\
\text { Paffas de Ciezar, à feis quartos la libra. } \\
\text { Alcaparras finas, à feis quartos la libra. } \\
\text { Alcaparras ordinarias, à quatro quartos la libra. }\end{array}$ & $m r$ \\
\hline
\end{tabular}

De cuyos precios no han de exceder los Tenderos, pena, que feràn caftigados por todo rigor de derecho. Y efte Aranm zel le tengan en parte donde quien compre le pueda leer con. facilidad. Dado en Toledo à I 6 . de Febrero de 1752.

\section{POR Acuerdo del Juzgado:}

Imagen 9. Arancel de tienda aprobado el 16 de diciembre de 1752. AMT Caja 55 bis. 
El formato de los aranceles es variado. Los específicos suelen ocupar una cara de un folio pero los generales tienen dimensiones mayores (doble folio o más) ${ }^{80}$. Y en los más grandes no siempre la disposición de su texto es apaisada. Por último, algunos de los conservados van validados con la firma y rúbrica autógrafa de los fieles ejecutores.

Estos aranceles se adherían a tablones de madera o a otras superficies similares. Algunos de los generales conservan en la actualidad restos de la sustancia que los mantenía pegados, lo que nos lleva a pensar que el Juzgado colocaba un ejemplar junto al lugar en el que celebraban sus audiencias y son estos los que luego hacía llegar al Ayuntamiento.

Ahora bien, no cabe duda de que debieron existir otras series documentales, además de las comentadas, en las que se reflejaran los precios de los alimentos en Toledo y, sobre todo, la cantidad que de cada uno de estos entraba en la ciudad para su abasto. De este control se encargaba el Real Peso de la Aduana que utilizaba "Libros del Peso de Mercado" o "Libros del Peso de la Real Aduana" (de ambas formas son denominados) para anotar todos los productos por los que se pagaba ese derecho una vez vendidos. Pero solo cuando se recaudaba por administración municipal, es decir cuando no había arrendatario ${ }^{81}$, quedaba constancia documental en el Ayuntamiento porque los administradores, nombrados por este, tenían que dar cuenta de todo lo ingresado. Y durante la Edad Moderna esta situación se produjo en Toledo en periodos muy concretos, si tenemos en cuenta los libros conservados en el Archivo Municipal. Los arrendatarios de este derecho no estaban obligados a entregar sus registros pues de ello nada se indicaba en sus escrituras de arrendamiento. En todo caso, en el Archivo se pueden consultar dieciséis libros de la administración municipal de la renta del Peso del Mercado o Real Aduana que se corresponden con los años 1656, $1737-1738,1740-1745,1748-1751,1755,1758$ y $1763^{82}$. Las anotaciones que recogen suelen iniciarse el $1^{\circ}$ de marzo y concluir a finales de febrero del año siguiente. Obviamente en ellos hay todo tipo de productos, no solo mantenimientos ${ }^{83}$, y las cantidades aparecen reflejadas de muy distintas maneras (fanegas, arrobas, libras, cargas, carguillas, banastas, banastillas, cubetas, pilones, costales, alforjas, sacos, barriles, pellejos, cántaros, docenas, pares, piezas, varas, manojos, pedazos...). Sus asientos siguen un orden cronológico y al final de cada mes se suele recoger la suma total de lo recaudado en ese periodo. Pero en estos libros no figuran los precios a los que fueron vendidos aunque sí sus cantidades y los derechos satisfechos por ellas. Lo interesante es que nos permiten conocer los nombres, y las localidades de origen o vecindad, de los trajineros y vendedores que en esos años abastecían Toledo. En otras ciudades había también registros con contenidos parecidos. ${ }^{84}$

${ }_{80}$ En el AMT conservamos uno de 59x39 cm fechado el 12 de mayo de 1813. Véase AMT, Fondo Histórico, caja 55 Bis.

${ }^{81}$ A veces la renta sí había sido arrendada pero el adjudicatario podía haber fallecido o producirse otras causas que le impedían cumplir con sus obligaciones.

82 Las signaturas de estos libros, ordenados por fechas, son las siguientes: Año 1656 (Libro núm. 342 ), 1737 (Ídem, núm. 343), 1738 (344), 1740 (345), 1741 (346), 1742 (347), 1743 (348), 1744 (349), 1745 (350), 1748 (351), 1749 (352), 1750 (353), 1751 (354), 1755 (355), 1758 (356) y 1763 (357). Son los mismos que los registrados en 1931 por Antonio Sierra Corella.

83 Además de alimentos, que son mayoritarios, aparecen todo tipo de tejidos, escobas, esparto, vidrio, etc. El Ayuntamiento de Toledo obtenía con esta renta importantes ingresos. En concreto, en 1739, su administración supuso cerca de 13.000 reales.

84 En la ciudad de León existía un Juzgado de Peso Real, o Peso Merchán, cuyos libros registro dan información sobre las cantidades que entraban de cada producto, y de su precio en venta al por mayor. Su estudio le ha sido 

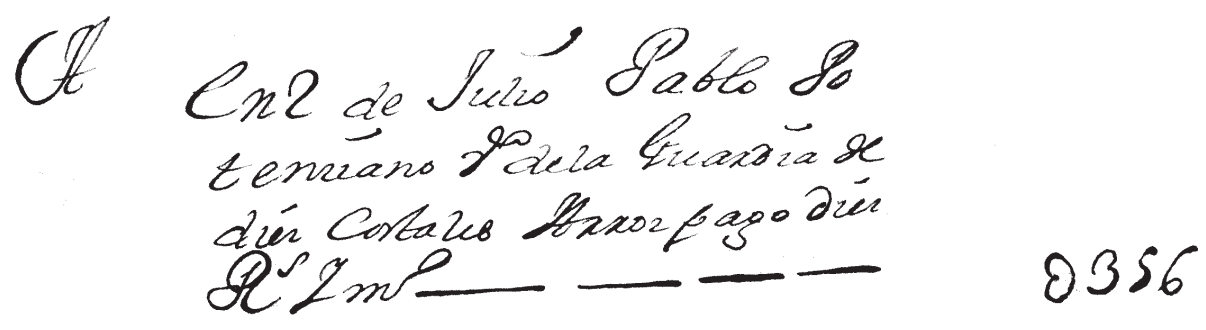

Imagen 10. Asiento en un Libro del Peso del Mercado de Toledo. 1737-07-02.

AMT, libro núm. $343 .{ }^{85}$

\section{Conclusiones}

El estudio de la evolución de los precios de los alimentos en la Edad Moderna, con la ayuda de las fuentes documentales municipales, se ha realizado en España utilizando básicamente la información recogida en los libros de acuerdos capitulares en los que solo figuran los productos básicos y de forma esporádica, especialmente cuando se producen problemas de abastecimiento. Algunas ciudades conservan, también, listas de precios, casi siempre de granos y legumbres, que han sido denominadas mercuriales. Los historiadores se han servido también de los expedientes tramitados para el arrendamiento de abastos mediante el sistema de obligados. Sin embargo, en este trabajo hemos querido incidir en la existencia de otras series singulares y de gran utilidad para elaborar estadísticas de precios, generadas por las corporaciones locales, de otros mantenimientos no considerados básicos pero que formaban parte de los hábitos de consumo en la época.

Entendemos que hemos puesto de manifiesto la importancia de los documentos municipales generados por los fieles ejecutores toledanos para el estudio de la evolución de los precios, de los hábitos de consumo, de la estacionalidad de los productos, del comercio interior y de otros aspectos relacionados con la vida cotidiana y la gastronomía. Y lo mismo ocurre con los generados en la ciudad de Madrid por el Repeso Mayor, con la particularidad de que en la capital las series son aún más completas. Es factible pensar que en otras ciudades castellanas pudieran conservarse registros similares aunque nuestras pesquisas no han dado los frutos esperados. Lo más normal es encontrar algún arancel impreso o manuscrito, incluido en unidades documentales denominadas como "expedientes de mercados", caso de Valladolid, o "expedientes de control de abastos y mercados", como en Coruña, la mayoría datados en el siglo XVIII. Aranceles impresos y posturas se custodian en el Archivo Municipal de Burgos $^{86}$, y en Córdoba existe un breve "Cuaderno de actas de diputaciones" de 1615-

muy útil a R. Cubillo de la Puente. Véase, por ejemplo, su libro Comer en León. Un siglo de Historia, León, Universidad, 2000.

85 Como ejemplo de estos asientos valga el que recogemos en esta imagen: "En 2 de julio [de 1737] Pablo Potenciano, vecino de la Guardia, de diez costales [de] arroz pagó diez reales y medio" [Al margen] "356" [mrs.]. Véase AMT, libro núm. 343.

86 En el Archivo Municipal de Burgos hay 112 documentos relacionados con su Juzgado de Fieles relativos a posturas, denuncias, actas desde 1551 a 1810. 
1616 con información sobre precios de alimentos ${ }^{87}$. En Oviedo, los libros registro de "regulación de valías y granos y legumbres" recogen datos seriados sobre el precio, al por mayor, de la escanda, el trigo, las habas, el maíz y la cebada, especialmente desde la segunda mitad del siglo XVIII ${ }^{88}$. En otras ciudades castellanas la situación debe ser muy similar.

Ante este panorama podemos afirmar que los libros registro elaborados por los fieles ejecutores de Madrid y de Toledo constituyen una fuente inexplotada y excepcionalmente valiosa para el estudio de la evolución de los precios en esas ciudades castellanas desde, al menos, la segunda mitad del siglo XVII y hasta los primeros años del siglo XIX.

87 También existen algunos privilegios, ejecutorias, provisiones, cédulas y otras escrituras, desde 1535 hasta 1815 , relacionados con los fieles ejecutores cordobeses que permiten realizar su estudio institucional.

88 Agradezco la información aportada por los archiveros municipales Eduardo Pedruelo (Valladolid), Ana Verdú (Córdoba), Milagros Moratinos (Burgos), Mariola Suárez (Coruña) y Ana Herrero (Oviedo). 